\title{
Simulating oxygen isotope ratios in tree ring cellulose using a dynamic global vegetation model
}

\author{
Sonja G. Keel ${ }^{1, a}$, Fortunat Joos ${ }^{1}$, Renato Spahni ${ }^{1}$, Matthias Saurer ${ }^{2}$, Rosemarie B. Weigt ${ }^{2}$, and Stefan Klesse ${ }^{3,4}$ \\ ${ }^{1}$ University of Bern, Physics Institute, Climate and Environmental Physics and Oeschger Centre for Climate Change \\ Research, Bern, Switzerland \\ ${ }^{2}$ Paul Scherrer Institute, Laboratory of Atmospheric Chemistry, Villigen, Switzerland \\ ${ }^{3}$ Swiss Federal Research Institute WSL, Birmensdorf, Switzerland \\ ${ }^{4}$ Oeschger Centre for Climate Change Research, Bern, Switzerland \\ anow at: Agroscope, Institute for Sustainability Sciences, Climate and Air Pollution, Zurich, Switzerland \\ Correspondence to: Sonja G. Keel (sonja.keel@agroscope.admin.ch)
}

Received: 20 October 2015 - Published in Biogeosciences Discuss.: 16 November 2015

Revised: 1 April 2016 - Accepted: 12 June 2016 - Published: 6 July 2016

\begin{abstract}
Records of stable oxygen isotope ratios in tree rings are valuable tools to reconstruct past climatic conditions and investigate the response of trees to those conditions. So far the use of stable oxygen isotope signatures of tree rings has not been systematically evaluated in dynamic global vegetation models (DGVMs). DGVMs integrate many hydrological and physiological processes and their application could improve proxy-model comparisons and the interpretation of oxygen isotope records. Here we present an approach to simulate leaf water and stem cellulose $\delta^{18} \mathrm{O}$ of trees using the LPX-Bern DGVM (LPX-Bern). Our results lie within a few per mil of measured tree ring $\delta^{18} \mathrm{O}$ of 31 different forest stands mainly located in Europe. Temporal means over the last 5 decades as well as interannual variations for a subset of sites in Switzerland are captured. A sensitivity analysis reveals that relative humidity, temperature, and the water isotope boundary conditions have the largest influence on simulated stem cellulose $\delta^{18} \mathrm{O}$, followed by all climatic factors combined, whereas increasing atmospheric $\mathrm{CO}_{2}$ and nitrogen deposition exert no impact. We conclude that simulations with LPX-Bern are useful for investigating large-scale oxygen isotope patterns of tree ring cellulose to elucidate the importance of different environmental factors on isotope variations and therefore help to reduce uncertainties in the interpretation of $\delta^{18} \mathrm{O}$ of tree rings.
\end{abstract}

\section{Introduction}

Stable oxygen isotope ratios $\left({ }^{18} \mathrm{O} /{ }^{16} \mathrm{O}\right)$ are widely used to reconstruct past climatic conditions and to characterize the modern hydrological cycle. $\delta^{18} \mathrm{O}$ $\left(\delta^{18} \mathrm{O}=\left[\left(\left({ }^{18} \mathrm{O} /{ }^{16} \mathrm{O}\right)_{\text {sample }} /\left({ }^{18} \mathrm{O} /{ }^{16} \mathrm{O}\right)_{\text {standard }}\right)-1\right] \times 1000\right.$ $(\% \circ))$ is routinely measured in various climate archives such as ice cores (Dansgaard, 1964; Johnsen et al., 2001; Jouzel et al., 2003; Severinghaus et al., 2009), speleothems (Fleitmann et al., 2004; McDermott, 2004), corals (Dunbar et al., 1994), ocean sediments (Shackleton and Obdyke, 1973; Elderfield and Ganssen, 2000), and tree rings (Libby et al., 1976; Treydte et al., 2006) as well as in modern precipitation samples (Rozanski et al., 1992; Kern et al., 2014). Regarding the tree ring archive, recent efforts were directed to document $\delta^{18} \mathrm{O}$ variability in stem cellulose from tree ring samples over the last millennium (e.g., Masson-Delmotte et al., 2005; Treydte et al., 2006; Edwards et al., 2008) and the industrial period (Anderson et al., 1998; Miller et al., 2006). The spatial distribution of tree ring $\delta^{18} \mathrm{O}$ has been characterized across large areas (e.g., Saurer et al., 2002; Herweijer et al., 2007; Treydte et al., 2007). In addition, attempts have been made to unravel the processes that determine stem cellulose $\delta^{18} \mathrm{O}$ (e.g., Gessler et al., 2009; Offermann et al., 2011).

The cycling of water isotopes through the climate system, including the transfer of water associated with gross primary productivity on land was successfully implemented in atmospheric general circulation and in Earth system models (Jous- 
saume et al., 1984; Jouzel et al., 1987; Hoffmann et al., 1998; Noone and Simmonds, 2002; Sturm et al., 2005; Werner et al., 2011) to characterize the hydrological cycle. Model results are used to demonstrate that the El Niño Southern Oscillation imprints a pronounced signal on water isotopes (Hoffmann et al., 1998) to reconstruct past precipitation patterns (Risi et al., 2010; Sjolte et al., 2011; Masson-Delmotte et al., 2015) and to explain $\delta^{18} \mathrm{O}$ paleo data (Hoffmann et al., 2003). Model results are evaluated against stable isotope ratios in precipitation (Joussaume et al., 1984), snow (Jouzel et al., 1987), ground water (Hoffmann et al., 1998), water vapor (Werner et al., 2011), and ice core $\delta^{18} \mathrm{O}$ data (e.g., Risi et al., 2010). Because none of these models describe $\delta^{18} \mathrm{O}$ in stem cellulose, a direct model-data comparison is not yet possible for tree rings and global-scale models. So far process models describing the transfer of isotopic signals from soil water and water vapor to leaf water, and finally to stem cellulose, were applied to single sites only (Roden et al., 2000; Ogée et al. 2009; Kahmen et al., 2011; Treydte et al., 2014). Yet, the implementation of such an approach in large-scale global land biosphere models is missing. A large-scale approach would have the advantage that many hydrological and physiological processes could be integrated, and large spatial and temporal patterns could be explored. Furthermore the importance of individual factors such as rising atmospheric $\mathrm{CO}_{2}$ could easily be examined.

The goals of this study are (i) to describe the implementation of the stable water isotope fluxes and pools in the LPX-Bern DGVM, including $\delta^{18} \mathrm{O}$ in stem cellulose for direct model-proxy comparison, (ii) to estimate the large-scale spatial distribution of $\delta^{18} \mathrm{O}$ in leaf water and stem cellulose, (iii) to quantify the drivers of spatiotemporal trends and variability of stem cellulose $\delta^{18} \mathrm{O}$ in the model context and to assist in the interpretation of tree ring $\delta^{18} \mathrm{O}$ data, and (iv) to assess the model performance for large-scale spatial gradients, multidecadal trends, and interannual variability with a focus on extratropical forests. We compiled time-averaged tree ring $\delta^{18} \mathrm{O}$ data from 31 boreal and temperate forest sites to capture spatial variability and use five tree ring- $\delta^{18} \mathrm{O}$ records from Switzerland to detail local temporal variability. Soil water and water vapor $\delta^{18} \mathrm{O}$ results from transient simulations with the model ECHAM5-JSBACH (Haese et al., 2013) over the past 50 years are used as oxygen isotope input data (i.e., isotope forcing). Factorial experiments at the site scale are performed to identify drivers of decadal trends and interannual variability.

\section{Isotope background}

Evaporation and condensation are the two processes that predominantly influence water oxygen isotope ratios in the climate system. Water molecules containing the lighter ${ }^{16} \mathrm{O}$ isotopes evaporate more readily compared to molecules containing the heavier ${ }^{18} \mathrm{O}$. Therefore moisture evaporated from the ocean is depleted in ${ }^{18} \mathrm{O}$ compared to ocean water, which has a $\delta^{18} \mathrm{O}$ of near $0 \%$. As air cools by rising into the atmosphere or moving toward the poles, moisture begins to condense and falls as precipitation. Water vapor molecules containing ${ }^{18} \mathrm{O}$ condense more readily and rain is enriched in ${ }^{18} \mathrm{O}$ compared to its vapor source. As the air continues to move poleward into colder regions (temperature effect) or further inland (continental effect), the remaining moisture in the air as well as the water that condenses and precipitates become increasingly more ${ }^{18} \mathrm{O}$-depleted. This is reflected in the spatial distribution of oxygen isotope ratios in soil water and water vapor. The $\delta^{18} \mathrm{O}$ of surface soil water reflects the $\delta^{18} \mathrm{O}$ signal of precipitation averaged over a certain amount of time and is further modified by evaporation of soil water leading to evaporative enrichment and potentially by mixing with ground water.

Plants take up water which carries this precipitation or soil water $\delta^{18} \mathrm{O}$ signature. During transport from roots to leaves, isotope ratios are not modified (Wershaw et al., 1966). In the leaves, water becomes enriched in ${ }^{18} \mathrm{O}$ relative to source water as a result of transpiration (Dongmann et al., 1974). The enrichment at the site of evaporation (the stomata) is primarily driven by the ratio of the vapor pressure outside vs. inside the leaf. Source water (i.e., soil water) that enters the leaf via the transpirational stream, mixes with the ${ }^{18} \mathrm{O}$-enriched water and dilutes the leaf water $\delta^{18} \mathrm{O}$ signal (a Péclet effect, Barbour et al., 2004). This Péclet effect tends to reduce the signal of evaporative enrichment in bulk leaf water (i.e., whole leaf water) and the effect is large when transpiration rates are high. Sucrose formed in the leaves is thought to be $27 \%$ o enriched in ${ }^{18} \mathrm{O}$ compared to leaf water due to fractionation during the exchange of oxygen between carbonyl groups in organic molecule and water (Sternberg et al., 1986). Sugars are then transported down the trunk where partial exchange with xylem water occurs before tree ring cellulose is formed (Roden et al., 2000; Gessler et al., 2014). Based on isotope theory, oxygen isotope ratios in tree rings serve as proxy data for relative humidity and reflect the signature of soil water (McCarroll and Loader, 2004). The relative strength of the humidity and soil water signal, however, is expected to vary due to the Péclet effect and oxygen isotope exchange during stem cellulose formation (see below) and is often difficult to quantify, which somewhat hampers current interpretation of tree ring results.

Tree ring chronologies have been found to correlate with relative humidity (Burk and Stuiver, 1981; An et al., 2014; $\mathrm{Xu}$ et al., 2014) and $\delta^{18} \mathrm{O}$ of precipitation (Waterhouse et al., 2002). In addition, tree ring $\delta^{18} \mathrm{O}$ archives are proxies, e.g., for precipitation amounts (Treydte et al., 2006), the occurrence of droughts (Masson-Delmotte et al., 2005; Herweijer et al., 2007) and tropical cyclones (Miller et al., 2006), or leaf-to-air vapor pressure differences (Kahmen et al., 2011).

Regarding tree rings, $\delta^{18} \mathrm{O}$ in stem cellulose has been described with mechanistic models to characterize the transfer of $\delta^{18} \mathrm{O}$ signals from soil water to stem cellulose (Roden et al., 2000; Cernusak et al., 2005; Barbour, 2007; Gessler et al., 
2009; Ogée et al., 2009). A formulation of leaf water enrichment at the site of evaporation (i.e., the stomata) based on the model by Craig and Gordon (1965) is common to all models, but additional processes related to $\delta^{18} \mathrm{O}$ signals in leaf water and stem cellulose are resolved at varying degrees of complexity. Some models include boundary layer considerations (Flanagan et al., 1991) or the Péclet effects that reduce leaf water enrichment (Barbour et al., 2004; Farquhar and Gan, 2003). Others account for variations in isotopic exchange of oxygen with xylem water (Barbour and Farquhar, 2000), or weight diurnal variations in leaf water enrichment by photosynthetic rates (Cernusak et al., 2005). Here, we use a rather general approach with a single Péclet effect and constant isotopic exchange with xylem water, as we aim to simulate stem cellulose across a large range of different species and as we lack detailed species-specific information, e.g., on water flow and the Péclet effect. On the other hand, we move a step forward in that we integrate a mechanistic model for stem cellulose $\delta^{18} \mathrm{O}$ into a DGVM that allows us to cover large spatial and temporal scales and that explicitly considers numerous hydrological and physiological processes.

\section{Material and methods}

\subsection{Model description}

Stable oxygen isotopes were implemented in the LPX-Bern DGVM (Land surface Processes and eXchanges, Bern version 1.0) (Spahni et al., 2013; Stocker et al., 2013). LPXBern describes the evolution of vegetation cover, carbon (C) and nitrogen $(\mathrm{N})$ dynamics in soil and vegetation, and the exchange of water, $\mathrm{CO}_{2}, \mathrm{C}$ isotopes, methane, and nitrous oxide between the atmosphere and the land biosphere.

The model version applied here features a horizontal resolution of $3.75^{\circ} \times 2.5^{\circ}$, a vertically resolved soil hydrology with heat diffusion and an interactive thawing-freezing scheme (Gerten et al., 2004; Wania et al., 2009), and features a daily time step for photosynthesis and evapotranspiration. The soil hydrology scheme is similar to a concurrent LPX version (Murray et al., 2011; Prentice et al., 2011). There are 10 plant functional types (PFTs) that have distinct bioclimatic limits and differ in their physiological traits such as minimum canopy conductance (Sitch et al., 2003) (Table S2 in Ruosch et al., 2016). The distribution of fine roots in the soil profile is also PFT-specific and leads to competition for water. Light competition is modeled indirectly by assigning a higher mortality to PFTs with a small increment in fractional plant cover and biomass compared to PFTs with a large increment (Sitch et al., 2003). Daily evapotranspiration is calculated for each PFT as the minimum of a plant- and soillimited supply function $\left(E_{\text {supply }}\right)$ and the demand for transpiration $\left(E_{\text {demand }}\right) . E_{\text {supply }}$ is the product of root-weighted soil moisture availability and a maximum water supply rate that is equal for all PFTs (Sitch et al., 2003). $E_{\text {demand }}$ is calculated following Monteith's (Monteith, 1995) empirical relation between evaporation efficiency and surface conductance:

$E_{\text {demand }}=E_{\mathrm{eq}} \alpha_{\mathrm{m}}\left[1-\exp \left(\frac{-g_{\mathrm{c}} \phi}{g_{\mathrm{m}}}\right)\right]$,

where $E_{\text {eq }}$ is the equilibrium evaporation rate, $g_{\mathrm{m}}$ and $\alpha_{\mathrm{m}}$ are empirical parameters that are equal for all plant functional types, $g_{\mathrm{c}}$ the canopy conductance, and $\phi$ the fraction of present foliage area to ground area (i.e., projected leaf area). Equation (1) is solved for $E_{\text {demand }}$ using the non-waterstressed potential canopy conductance as calculated by the photosynthesis routine for a fixed ratio $\lambda$ between the $\mathrm{CO}_{2}$ mole fraction in the stomatal cavity and the ambient air. $\lambda$ is set equal to 0.8 following Sitch et al. (2003) to approximate non-water-stressed conditions and as a starting value for the iterative computation of carbon assimilation and transpiration. In case of water-stressed conditions when $E_{\text {demand }}$ exceeds $E_{\text {supply }}$, canopy conductance and photosynthesis are jointly and consistently down-regulated; $E_{\text {demand }}$ is set to $E_{\text {supply }}$ and Eq. (1) is solved for $g_{\mathrm{c}}$.

Photosynthesis is modeled following Collatz et al. (1991, 1992), which is based on the formulations by Farquhar et al. (1980) and Farquhar and von Caemmerer (1982) generalized for global modeling purposes. The $\mathrm{N}$ content and $\mathrm{Ru}-$ bisco activity of leaves are assumed to vary seasonally and with canopy position in a way to maximize net assimilation at the leaf level. For $\mathrm{C}_{3}$ plants assimilation is a function of the daily integral of absorbed photosynthetically active radiation. For a detailed description see Haxeltine and Prentice (1996a, b).

Canopy conductance, $g_{\mathrm{c}}$, is linked to daytime assimilation, $A_{\mathrm{dt}}$, through

$g_{\mathrm{c}}=g_{\min }+\frac{1.6 A_{\mathrm{dt}}}{\left[c_{\mathrm{a}}(1-\lambda)\right]}$,

where $g_{\min }$ is a PFT specific minimum canopy conductance, $c_{\mathrm{a}}$ is the ambient mole fraction of $\mathrm{CO}_{2}$, and $\lambda$ the ratio between the $\mathrm{CO}_{2}$ mole fraction in the stomatal cavity and the ambient air. The equations for water supply and demand, assimilation, and canopy conductance are solved simultaneously by varying $\lambda$ to yield self-consistent values for $\lambda, g_{\mathrm{c}}$, assimilation, and transpiration.

\subsection{Leaf water and stem cellulose $\delta^{18} \mathrm{O}$ model}

To calculate $\delta^{18} \mathrm{O}$ in leaf water we use the Péclet modified Craig-Gordon (PMCG) model as described, e.g., in Farquhar and Lloyd (1993).

The evaporative enrichment of leaf water above the plant's source water at the site of evaporation $\left(\Delta^{18} \mathrm{O}_{\mathrm{e}}\right)$, is based on the Craig-Gordon formulation (Craig and Gordon, 1965; Dongmann et al., 1974).

$\Delta^{18} \mathrm{O}_{\mathrm{e}}=\varepsilon^{+}+\varepsilon_{\mathrm{k}}+\left(\Delta^{18} \mathrm{O}_{\mathrm{v}}-\varepsilon_{\mathrm{k}}\right) \frac{e_{\mathrm{a}}}{e_{i}}$, 
where $\varepsilon^{+}$is the temperature-dependent equilibrium fractionation factor between liquid and vapor water and is calculated as

$\varepsilon^{+}=2.644-3.206\left(\frac{10^{3}}{T_{1}}\right)+1.534\left(\frac{10^{6}}{T_{1}^{2}}\right)(\% o)$,

with $T_{1}$ as the leaf temperature in $\mathrm{K}$ (Bottinga and Craig, 1969; Barbour, 2007). $\varepsilon^{+}$increases with decreasing temperature and is around $8.8 \%$ at $30^{\circ} \mathrm{C}$ and around $11.5 \% \circ$ at $0{ }^{\circ} \mathrm{C}$. $\varepsilon_{\mathrm{k}}$ is the kinetic fractionation factor for water vapor diffusion from the leaf to the atmosphere (32\%; Cappa et al., 2003), $\Delta{ }^{18} \mathrm{O}_{\mathrm{v}}$ describes the oxygen isotope enrichment of water vapor in the atmosphere above source water, and $e_{\mathrm{a}} / e_{\mathrm{i}}$ is the ratio of ambient-to-intercellular vapor pressures. This ratio is equal to relative humidity when leaf and air temperatures are similar and $e_{\mathrm{i}}$ is at saturation pressure. We assume that leaf temperature is approximated by air temperature (see also Discussion). We use this formulation in LPX-Bern for the comparison against published leaf water $\delta^{18} \mathrm{O}$ (West et al., 2008).

All other results were derived with the expanded model that includes a Péclet effect. The Péclet number is defined as

$\wp=\frac{L E}{c D}$,

and accounts for the dilution of ${ }^{18} \mathrm{O}$-enriched leaf water by unenriched source water that enters the leaf via the transpirational stream $\left(E, \mathrm{~mol} \mathrm{~m}^{-2} \mathrm{~s}^{-1}\right)$ and is effective over a path length $L$ (Farquhar and Lloyd, 1993). To keep the model as simple as possible, we set $L$ to $0.03 \mathrm{~m}$ for all PFTs following Kahmen et al. (2011), although $L$ can vary largely between species (Kahmen et al., 2009). $c$ is the molar density of water $\left(55.5 \times 10^{3} \mathrm{~mol} \mathrm{~m}^{-3}\right)$ and $D$ the temperature-dependent diffusivity of $\mathrm{H}_{2}^{18} \mathrm{O}$ in water (Cuntz et al., 2007, Eq. (A22), typo corrected: $10^{-8}$ instead of $10^{-9}$ ):

$D=10^{-8} \exp \left(-0.4+\frac{1528}{T_{1}}+\frac{-554368}{T_{1}^{2}}\right)\left(\mathrm{m}^{2} \mathrm{~s}^{-1}\right)$.

Bulk leaf water ${ }^{18} \mathrm{O}$ enrichment can then be calculated as

$\Delta^{18} \mathrm{O}_{\mathrm{LW}}=\frac{\Delta^{18} O_{\mathrm{e}}\left(1-e^{-\wp}\right)}{\wp}$.

$\Delta^{18} \mathrm{O}_{\mathrm{LW}}$ is smaller than $\Delta^{18} \mathrm{O}_{\mathrm{e}}$ and approaches $\Delta^{18} \mathrm{O}_{\mathrm{e}}$ for small transpiration rates $E$. In regions with high leaf transpiration rates, the reduction of $\Delta^{18} \mathrm{O}_{\mathrm{e}}$ due to the Péclet effect is most strongly expressed (Fig. S1 in the Supplement). Leaf water $\delta^{18} \mathrm{O}$ is

$\delta^{18} O_{\mathrm{LW}}=\Delta^{18} O_{\mathrm{LW}}+\delta^{18} O_{\mathrm{SW}}$, where $\delta^{18} \mathrm{O}_{\mathrm{SW}}$ refers to soil water $\delta^{18} \mathrm{O}$. Stem cellulose isotopic composition is calculated as

$$
\begin{aligned}
& \delta^{18} \mathrm{O}_{\mathrm{SC}}=p_{\mathrm{ex}} p_{x}\left(\delta^{18} \mathrm{O}_{\mathrm{SW}}+\varepsilon_{\mathrm{wc}}\right) \\
& +\left(1-p_{\mathrm{ex}} p_{x}\right)\left(\delta^{18} \mathrm{O}_{\mathrm{LW}}+\varepsilon_{\mathrm{wc}}\right) \\
& =\delta^{18} \mathrm{O}_{\mathrm{SW}}+\left(1-p_{\mathrm{ex}} p_{x}\right) \Delta^{18} \mathrm{O}_{\mathrm{LW}}+\varepsilon_{\mathrm{wc}},
\end{aligned}
$$

where $\varepsilon_{\mathrm{wc}}$ is the fractionation between $\delta^{18} \mathrm{O}$ of water and the $\delta^{18} \mathrm{O}$ of the primary products of photosynthesis of $27 \%$ o (Epstein et al., 1977), $p_{\mathrm{ex}}$ is the proportion of exchangeable oxygen in cellulose formed from sucrose, and $p_{x}$ is the proportion of $\delta^{18} \mathrm{O}_{\mathrm{SW}}$ at the site of cellulose formation (Roden et al., 2000). For our simulations we used values of 0.4 for $p_{\text {ex }}$ (Cernusak et al., 2005; Sternberg, 2009) and 1.0 for $p_{x}$ (Kahmen et al., 2011).

Photosynthesis and plant water fluxes, thus changes in leaf water and stem cellulose $\delta^{18} \mathrm{O}$, are computed with a daily time step. Because stem cellulose formation is restricted to the vegetation period in temperate and boreal regions, we apply positive net primary production (NPP) as a weight to compute time-averaged stem cellulose and leaf water $\delta^{18} \mathrm{O}$ and apply a cutoff of $1.0 \mathrm{~g} \mathrm{C} \mathrm{m}^{-2}$ month $^{-1}$. This means that annual $\delta^{18} \mathrm{O}$ of stem cellulose is calculated only based on months with a NPP higher than $1.0 \mathrm{~g} \mathrm{C} \mathrm{m}^{-2}$ month $^{-1}$ and days with high NPP have a stronger weight. Effects of $\mathrm{C}$ storage related to the incorporation of photoassimilates from previous years into the current year's cellulose are not accounted for (Gessler et al., 2007).

\subsection{Input data}

Monthly gridded meteorological data (temperature, precipitation, cloud cover, and number of wet days (CRU TS v. 3.21 Climatic Research Unit; Harris et al., 2014)), annual atmospheric N-deposition fields (Lamarque et al., 2011), and atmospheric $\mathrm{CO}_{2}$ (Etheridge et al., 1998; MacFarling Meure et al., 2006) are prescribed to LPX-Bern. The meteorological data are linearly interpolated to daily values, except for precipitation where a stochastic weather generator is applied to compute daily precipitation following Gerten et al. (2004). Monthly soil water $\delta^{18} \mathrm{O}$, water vapor $\delta^{18} \mathrm{O}$, and relative humidity data are from a simulation with the coupled atmosphere-land surface model ECHAM5-JSBACH for the period 1960 to 2012 (Haese et al., 2013) .

Next, the CRU climate input data are briefly evaluated. For five tree ring sites in Switzerland (see Sect. 2.5), we compared the CRU climate input data against relative humidity from meteorological stations (Source MeteoSwiss) and homogenized air temperature and precipitation data for Switzerland (Begert et al., 2005). For the high-elevation site at Davos (DAV), summertime (June-August, JJA) precipitation and relative humidity input data are slightly higher than data from meteorological stations in the 1960s and 1970s and similar thereafter. Air temperatures for the corresponding 
pixel from the gridded CRU data set are around $4{ }^{\circ} \mathrm{C}$ higher than in the MeteoSwiss data at DAV, as the CRU data represent averages for a large area. The CRU data for the sites LOV (Lötschen Valley) and LOT (Lötschen Treeline) compare relatively well with the meteorological station data, except for higher precipitation (both sites) and higher air temperature (site LOT).

A first-order correction is applied to the relative humidity data from ECHAM5-JSBACH to account for the daily cycle. Leaf water ${ }^{18} \mathrm{O}$ enrichment is driven by daytime relative humidity (when stomata are open), whereas the available ECHAM5-JSBACH data represent $24 \mathrm{~h}$ averages. Relative humidity is reduced uniformly by an absolute value of $10 \%$ based on a comparison of $24 \mathrm{~h}$ against 8:00-18:00 LT summertime average relative humidity values in temperate and boreal regions (Kearney et al., 2014). This correction was evaluated for a few summer days at the site DAV and found to be sufficient.

ECHAM5-JSBACH includes the atmosphere model ECHAM5 (Roeckner et al., 2003), and the land surface scheme JSBACH (Jena Scheme for Biosphere-Atmosphere Interaction in Hamburg; Raddatz et al., 2007). The model comprises three surface water reservoirs: a snow layer, water at the skin layer of the canopy or bare soil, and a soil water layer. These three pools are each represented by a single layer bucket model, and each of them has a prescribed maximum field capacity. In ECHAM5-JSBACH, there are no soil layers and the isotopic composition has no vertical gradient. Any water taken up by plants has the $\delta^{18} \mathrm{O}$ of soil water. The soil layers in LPX-Bern do not affect the isotopic composition, but are exclusively used for quantitative assessment of water pools and fluxes. The drainage to groundwater in ECHAM5-JSBACH has the isotopic composition of the soil water. No fractionation during snowmelt is assumed. Liquid precipitation and melt water are added to the skin layer reservoir and the soil reservoir, respectively. After these reservoirs are filled, the residual water yields the runoff.

In order to calculate evapotranspiration in ECHAM5JSBACH, each grid cell is divided into four cover fractions: one covered by snow, one covered with water in the skin layer reservoir, one covered by vegetation, and one covered by bare soil. The complete evapotranspiration flux is calculated by the weighted sum of these four fractions. The skin layer is modeled as a thin layer of water, which in general evaporates completely within a few model time steps.

\subsection{Simulations}

A spinup of 1500 years is performed with LPX-Bern, where an analytical solution for the $\mathrm{C}$ inventory in slow soil pools is applied after 1000 years to ensure that all $\mathrm{C}$ pools have established equilibrium conditions by the end of the spinup. Atmospheric $\mathrm{CO}_{2}$ concentrations of the year 1900, atmospheric $\mathrm{N}$ deposition rates of 1901 , climate data from 1901 to 1931 , and $\delta^{18} \mathrm{O}$ input data for 1960 are used during the spinup.
Transient simulations are started in 1901 forced by atmospheric $\mathrm{CO}_{2}$, annual $\mathrm{N}$ deposition (Lamarque et al., 2011), and monthly climate (see Sect. 2.3). For the years 1901-1960 we use monthly relative humidity, soil water $\delta^{18} \mathrm{O}$ and vapor $\delta^{18} \mathrm{O}$ of 1960 and 1960-2012 data thereafter. All runs are for potential vegetation (no land use) and feedbacks between $\mathrm{C}$ and $\mathrm{N}$ cycles are enabled (i.e., potential limitation of growth by low $\mathrm{N}$ availability).

In factorial simulations, model parameters or input data are increased individually by $10 \%$ and the impact is evaluated for stem cellulose $\delta^{18} \mathrm{O}$ for the June, July, and August 1960 average for the grid cell that includes the site DAV. In another suite of sensitivity experiments, the influence of 20th century trends and variability on simulated $\delta^{18} \mathrm{O}$ is explored (see Sect. 3.3). Individual input data are kept at initial conditions while all others are prescribed as in the standard simulation. For these sensitivity experiments, monthly means of 1901-1931 are applied for air temperature, precipitation, cloud cover, and number of wet days), and monthly means of 1960-1969 for relative humidity, soil water $\delta^{18} \mathrm{O}$ and water vapor $\delta^{18} \mathrm{O}$, and 1901 values for atmospheric $\mathrm{CO}_{2}$ and $\mathrm{N} \mathrm{de}-$ position. In a similar factorial experiment, the Péclet effect is excluded. The time series are smoothed using Stineman functions. For the site DAV we carry out an additional series of experiments to evaluate the influence of a $3.5^{\circ} \mathrm{C}$ lower leaf than air temperature (because the 1960-2012 mean measured temperature is $3.5^{\circ} \mathrm{C}$ lower than the CRU temperature used in LPX-Bern), a temperature-dependent biochemical fractionation as described in Sternberg and Ellsworth (2011),

$\varepsilon_{\mathrm{wc}}=0.0084 T^{2}-0.51 T+33.172$,

and this temperature-dependent biochemical fractionation with measured air temperature prescribed instead of the default CRU data, while all other terms remain unchanged.

\subsection{Tree ring $\delta^{18} O$ data}

To validate our model with regard to spatial variations, we compare mean $\delta^{18} \mathrm{O}$ of stem cellulose for the years 1960-1996 (or until 2012 depending on availability of data) against observations from 31 sites in temperate and boreal forests (Treydte et al., 2006, 2007, 2009; Kress et al., 2010; Holzkämper et al., 2008). The sites span an area from Spain to Pakistan in the east-west and from Morocco to Finland in the north-south, but the majority of the area is located in Europe. Measurements were performed on different tree species. In most cases, the corresponding plant functional type (temperate broad-leaved deciduous, temperate or boreal needle-leaved evergreen, or boreal needle-leaved deciduous) is simulated by LPX-Bern at the location of interest and used for model-data comparison. Otherwise, we use simulated $\delta^{18} \mathrm{O}$ values of the dominant tree plant functional type simulated by the model. This is permissible as the differences in $\delta^{18} \mathrm{O}$ between functional types are rather minor (see below). 
Five sites in Switzerland were chosen for a comparison of time series (Table S1). DAV is a west-facing site at $1660 \mathrm{~m}$ above sea level (a.s.1.), dominated by the evergreen Picea abies (L.) H. Karst near the village of Davos. The sites on the mountain Lägern (LAEA and LAEB), situated on similar altitudes of about $720 \mathrm{~m}$ a.s.l., have a southern aspect, but are on different soil types. Site LAEA is on sandstone and is dominated by the deciduous broad-leaved Fagus sylvatica L. and the evergreen needle-leaved Abies alba Mill., the site LAEB is on limestone and is dominated by the two deciduous broad-leaved species $F$. sylvatica and Fraxinus excelsior L. However, only F. sylvatica is analysed here. The northfacing site in the Lötschen Valley (N19) is at $2000 \mathrm{~m}$ a.s.l. and is dominated by the evergreen P. abies. Close by is an additional site LOE in the Lötschen Valley at $2100 \mathrm{~m}$ a.s.l. that has a south-north exposure and is dominated by $L$. decidua (Kress et al., 2010).

For two additional sites in the Lötschen Valley at 1350 and $2100 \mathrm{~m}$ a.s.l. (LOV, LOT), a complete set of input data at about biweekly resolution for the year 2008 including soil and needle water $\delta^{18} \mathrm{O}$ for Larix decidua $\mathrm{L}$. was available (Treydte et al., 2014). The site LOT is in immediate neighborhood to the site LOE but different trees were sampled at the two sites. In contrast to all other sites, whole wood $\delta^{18} \mathrm{O}$ was analyzed instead of cellulose. We therefore increased the whole wood values by $4.0 \%$ to convert them to cellulose, according to the constant difference documented in larch for the last decades (Sidorova et al., 2008).

While most of these measured tree ring $\delta^{18} \mathrm{O}$ chronologies were derived from pooled samplings of 4-5 dominant trees (Treydte et al., 2007; Kress et al., 2010), the data set of the sites DAV, LAEA, LAEB, and N19 was based on measurements of individual trees, sampled within the framework of the present study. Here, the sampling design covered not only dominant but also smaller trees within a circular plot of about $30 \mathrm{~m}$ in diameter, in order to account for the full range of tree ring isotopic signature within a stand (Babst et al., 2014). From about 10 trees per site, stable oxygen isotope ratios were measured separately for each selected tree and each year over the full length of the sampled cores. Tree ring cellulose was extracted prior to measurement of $\delta^{18} \mathrm{O}$ via pyrolysis (PYRO-cube, Elementar, Hanau, Germany) and analysed for $\delta^{18} \mathrm{O}$ by isotope ratio mass spectrometry (Delta Plus XP IRMS, ThermoFinnigan MAT, Bremen, Germany), as described in Weigt et al. (2015). Mean values of the individual trees per year were used for site-specific $\delta^{18} \mathrm{O}$ chronologies.

\section{Results}

\subsection{Large-scale, global patterns of $\delta^{18} \mathrm{O}$ in soil water, leaf water, and stem cellulose}

We first analyze the large-scale, global patterns of $\delta^{18} \mathrm{O}$ in soil and leaf water and in stem cellulose to identify charac-

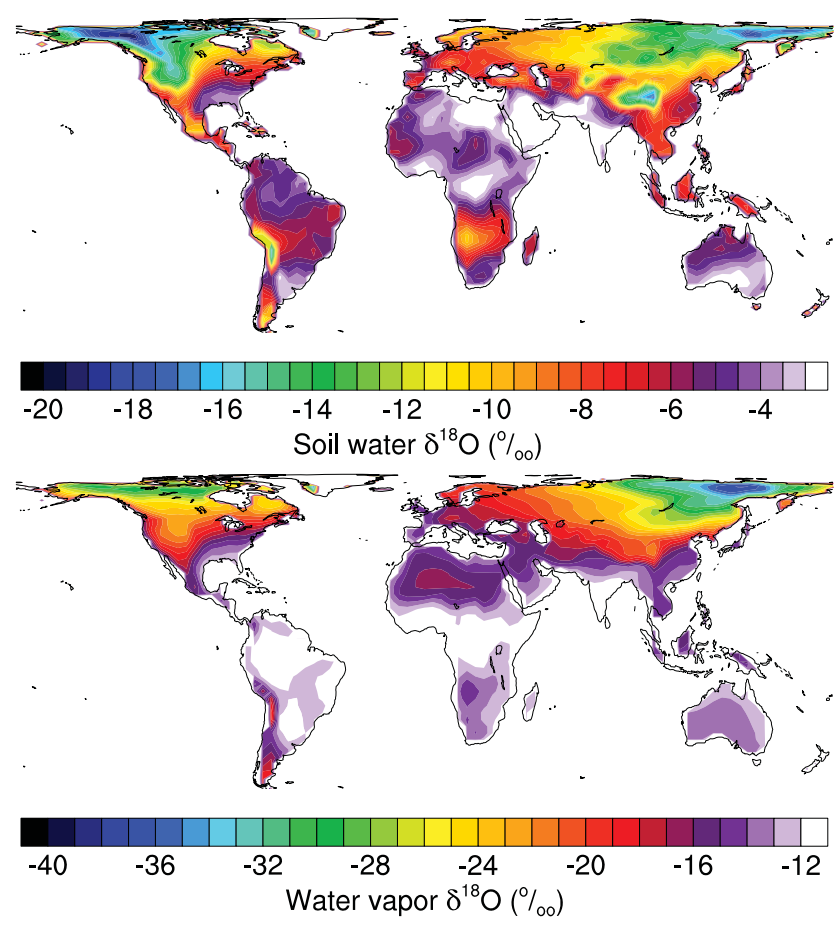

Figure 1. Simulated monthly soil water $\delta^{18} \mathrm{O}$ (upper panel) and water vapor $\delta^{18} \mathrm{O}$ (lower panel) were used as input data for the calculation of leaf water and cellulose $\delta^{18} \mathrm{O}$ by LPX-Bern. The presented data were simulated by the coupled atmosphere-land surface model ECHAM5-JSBACH (Haese et al., 2013). Average values for 19611990 are shown.

teristic features and to evaluate the plausibility of simulated results. Annual mean soil water $\delta^{18} \mathrm{O}$ values simulated by ECHAM5-JSBACH range between -1 and $-21 \%$ (19601990; Fig. 1) and are in the same range as reconstructions of $\delta^{18} \mathrm{O}$ in precipitation from the Global Network for Isotopes in Precipitation (GNIP) database (Bowen and Revenaugh, 2003). For precipitation, Haese et al. (2013) estimates that the root mean square error between precipitation $\delta^{18} \mathrm{O}$ simulated by ECHAM5-JSBACH and the GNIP data is $1.78 \%$. The simulated soil water $\delta^{18} \mathrm{O}$ pattern represents major features as identified for $\delta^{18} \mathrm{O}$ in precipitation (e.g., Bowen and Revenaugh, 2003). Namely, a decrease in $\delta^{18} \mathrm{O}$ from midlatitudes to high latitudes, lower signatures at high elevation, and a decrease from coastal regions towards the continental interior. The simulated soil water $\delta^{18} \mathrm{O}$ pattern generally agrees with the pattern interpolated for precipitation from the GNIP data (Bowen and Revenaugh, 2003).

Simulated leaf water $\delta^{18} \mathrm{O}$ averaged across all plant functional types range from about $-14 \%$ at high latitudes to about $28 \%$ in the Middle East (Fig. 2, upper panel). Thus, the simulated $\delta^{18} \mathrm{O}$ values in leaf water at the grid cell and climatological scale span a range of $\sim 40 \%$ o. $\delta^{18} \mathrm{O}$ values in leaf water result from the combination of soil water $\delta^{18} \mathrm{O}$ and evaporative enrichment. There are also substantial re- 


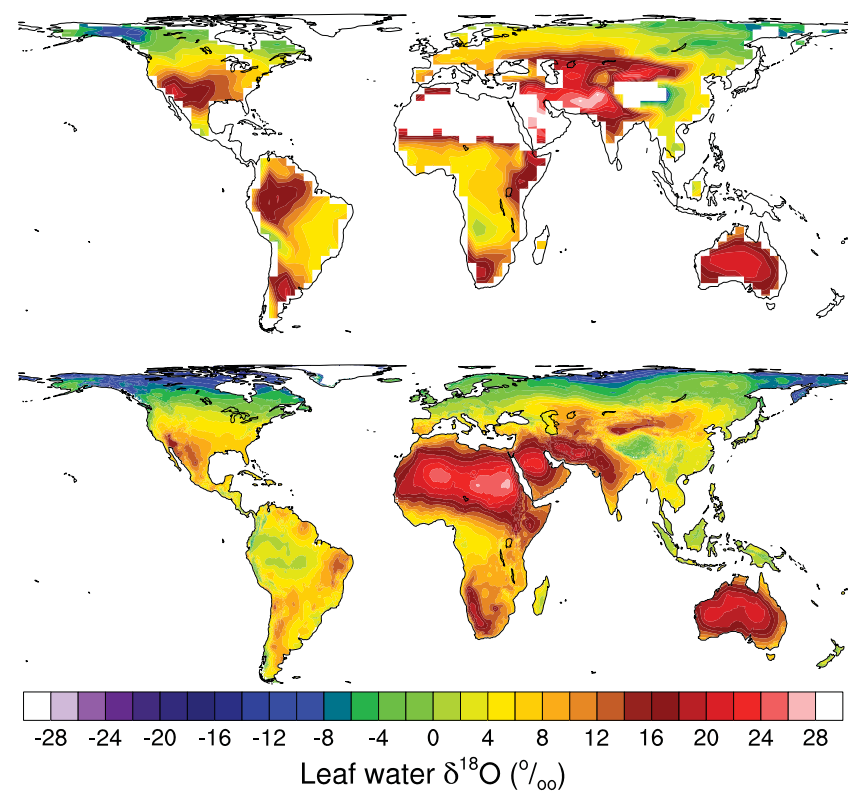

Figure 2. Leaf water $\delta^{18} \mathrm{O}(\%$ ) as simulated by LPX-Bern (upper panel) compared to results by West et al. (2008) using a GIS approach (lower panel). LPX-Bern results are shown for the years 1961-1990 using the Craig-Gordon formulation (i.e., no Péclet effect) for comparability and for all plant functional types including grasses and herbs.

gional differences in the evaporative enrichment of $\delta^{18} \mathrm{O}$ in leaf water mainly due to large differences in air humidity, i.e., higher enrichment in arid regions than high latitude regions (Fig. 3a). These differences are much larger than the differences between annual mean $\delta^{18} \mathrm{O}$ in soil water from ECHAM5-JSBACH and reconstructed $\delta^{18} \mathrm{O}$ in precipitation discussed in the previous paragraph. This suggests that soil water $\delta^{18} \mathrm{O}$ fields from ECHAM5 provide a reasonable input to force LPX-Bern simulations and that evaporative enrichment is a major process shaping the spatial pattern in leaf water $\delta^{18} \mathrm{O}$.

West et al. (2008) combined annual average $\delta^{18} \mathrm{O}$ data in precipitation (Bowen and Revenaugh, 2003), monthly climatology for air temperature and relative humidity, and elevation data with the Craig-Gordon formulation for evaporative enrichment to estimate leaf water $\delta^{18} \mathrm{O}$. Our values roughly agree with the geographic information system (GIS) model by West et al. (2008) (Fig. 2, lower panel), but differences exist in many regions. Our estimates tend to be substantially higher, e.g., in western Amazonia, central Siberia and the Middle East, while they are significantly lower for small regions in central Africa and China. Leaf water $\delta^{18} \mathrm{O}$ in Australia and eastern Russia agree comparatively well.

Differences in simulated leaf water $\delta^{18} \mathrm{O}$ between the two approaches are much larger than differences between annual mean $\delta^{18} \mathrm{O}$ in precipitation, used by West et al. (2008) as input to their GIS approach, and annual mean $\delta^{18} \mathrm{O}$ in soil water from ECHAM5-JSBACH. Thus, uncertainties in the source water input data do not explain the differences between the two approaches. The mechanistic approach implemented in LPX-Bern to model leaf water isotopic signatures considers seasonally varying $\delta^{18} \mathrm{O}$ of both source water and atmospheric water vapor, and models explicitly daily stomatal conductance, transpiration, and associated $\delta^{18} \mathrm{O}$ transport. This might explain the differences.

Tree ring cellulose $\delta^{18} \mathrm{O}$ is in the expected range for most regions (Fig. 3b). Generally values are higher in arid regions and lower at high latitudes and range between 15 and $35 \%$ o (Saurer et al., 2002; Ferrio and Voltas, 2005). When comparing leaf water and stem cellulose $\delta^{18} \mathrm{O}$ with the $\delta^{18} \mathrm{O}$ forcing used (Figs. 1, 2, 3b), it is obvious that soil water, leaf water, and cellulose $\delta^{18} \mathrm{O}$ share a common pattern as described above. However, the simulated range of $\delta^{18} \mathrm{O}$ in cellulose is comparable to the $\delta^{18} \mathrm{O}$ range in soil water (or precipitation), but only half as large as the $\delta^{18} \mathrm{O}$ range in leaf water. Due to biochemical fractionation during cellulose synthesis $\left(\varepsilon_{\mathrm{wc}}\right)$, cellulose $\delta^{18} \mathrm{O}$ is up to $27 \%$ o higher compared to leaf water $\delta^{18} \mathrm{O}$ and cellulose depends linearly on leaf water $\delta^{18} \mathrm{O}$. The difference between stem cellulose and leaf water $\delta^{18} \mathrm{O}$ can be calculated by combining equations 8 and 9 and this yields a simple linear relationship with leaf water enrichment $\left(\delta^{18} \mathrm{O}_{\mathrm{SC}}-\delta^{18} \mathrm{O}_{\mathrm{LW}}=\varepsilon_{\mathrm{wc}}-p_{\mathrm{ex}} p_{x} \Delta^{18} \mathrm{O} \mathrm{LW}\right.$, where $p_{\mathrm{ex}} p_{x}$ is 0.4 and $\varepsilon_{\mathrm{wc}}=27 \%$ ). The difference between cellulose and leaf water $\delta^{18} \mathrm{O}$ is thus highest in regions with very low leaf water enrichment such as at high latitudes. The simulated enrichment of stem cellulose with respect to soil water is also proportional to leaf water enrichment $\left(\delta^{18} \mathrm{O}_{\mathrm{SC}}-\delta^{18} \mathrm{O}_{\mathrm{SW}}=\Delta^{18} \mathrm{O}_{\mathrm{LW}}\left(1-p_{\mathrm{ex}} p_{x}\right)+\varepsilon_{\mathrm{wc}}\right)$. The slope of this relationship is with $0.6\left(1-p_{\mathrm{ex}} p_{x}, p_{\mathrm{ex}} p_{x}=0.4\right)$ smaller than unity, which explains the smaller spatial gradients in stem cellulose $\delta^{18} \mathrm{O}$ compared to leaf water $\delta^{18} \mathrm{O}$.

\subsection{Comparison of simulated stem cellulose $\delta^{18} \mathrm{O}$ with tree ring data}

Next, we quantitatively evaluate simulated $\delta^{18} \mathrm{O}$ in stem cellulose by comparing modeled long-term $(\sim 50 \mathrm{yr})$ averages at individual grid cells with measured $\delta^{18} \mathrm{O}$ from local, sitespecific tree ring data (Table S1). We recall that LPX-Bern is run with a resolution of $3.75^{\circ} \times 2.5^{\circ}$ which implies mismatches between local site conditions (altitude, climate, etc.) and grid cell averages as used to force the model. Nevertheless, simulated stem cellulose $\delta^{18} \mathrm{O}$ agrees well with measured tree ring data from 31 sites mainly located in European temperate and boreal forests (circles in Figs. 3b, 4). The model captures the observation-based range in $\delta^{18} \mathrm{O}$ for these sites from about 26 to $32 \%$ and the correlation between model and tree ring data is $r=0.71$ across all data points. In general the model tends to underestimate $\delta^{18} \mathrm{O}$ values of stem cellulose. Modeled grid cell values at five Swiss sites, which will be used to explore temporal dynamics, also show somewhat lower $\delta^{18} \mathrm{O}$ in stem cellulose $(0-2 \%$ ) than the tree ring 
(a)
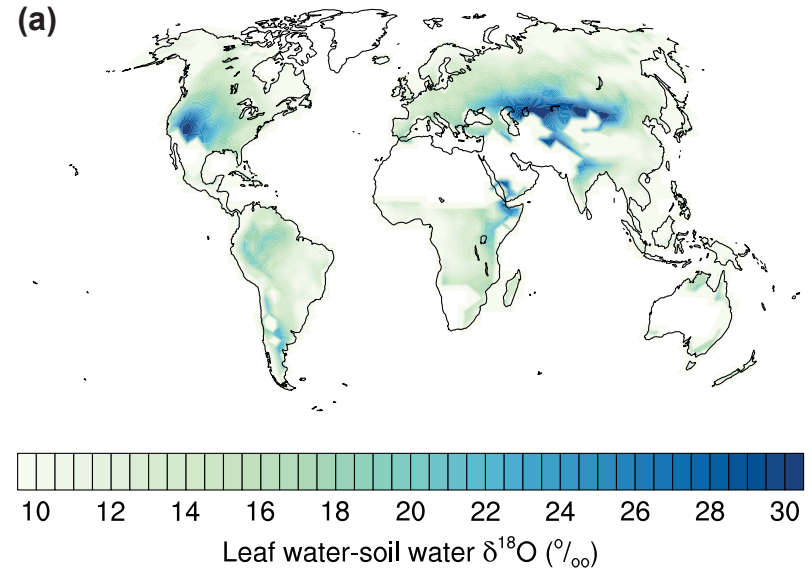

(b)
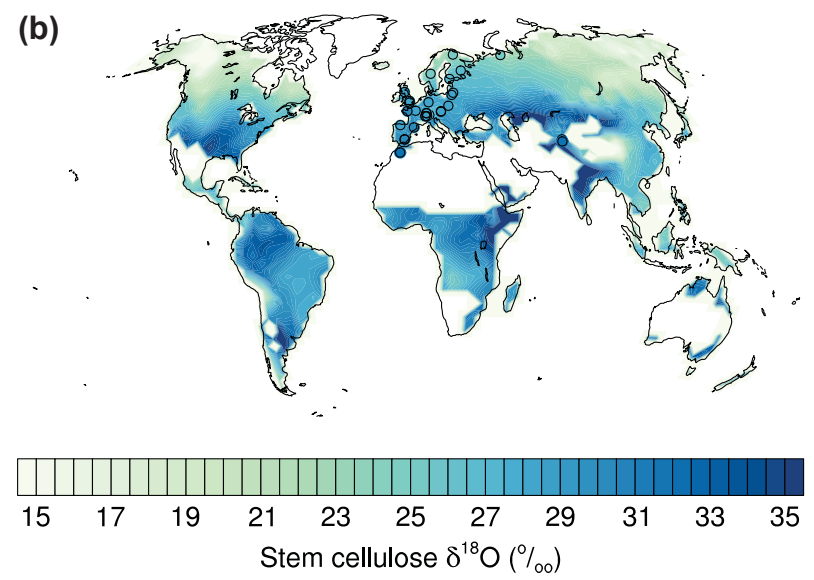

Figure 3. Leaf water ${ }^{18} \mathrm{O}$ enrichment above soil water $\delta^{18} \mathrm{O}$ (a) and stem cellulose $\delta^{18} \mathrm{O}(\mathbf{b})$ averaged over all tree plant functional types and over 1961-2012 as simulated by LPX-Bern. Colored circles in (b) show temporally averaged results from local tree ring data (Table S1 in the Supplement) on the same color scale as model results.

$\delta^{18} \mathrm{O}$ data suggest (Fig. 5). This holds for the alpine, high altitude sites at DAV (Fig. 5a) and in the Lötschen Valley (N19, LOE; Fig. 5j, k) as well as for the low-lying sites in the Swiss Central Plateau (LAEA, LAEB; Fig. 5h, i). The low bias is most strongly expressed at sites where the model is forced by very high relative humidity (annual mean 19602012 weighted by NPP is $>80 \%$; Fig. 4 green symbols; sites FON, GUT, INA, LIL, MOT). This bias at high humidity sites could potentially arise from a bias in $\delta^{18} \mathrm{O}$ of soil water, in $\delta^{18} \mathrm{O}$ of water vapor, or in relative humidity and thus vapor pressure deficit, and it could be related to differences in the spatial scale, i.e., local measurements at individual trees vs. averages over all trees of a plant functional type and over a grid cell. We note that daily average relative humidity is reduced by $10 \%$ for the simulation of leaf water $\delta^{18} \mathrm{O}$ to account for the lower daytime vs. $24 \mathrm{~h}$ humidity; uncertainties in this correction have a larger influence on the water vapor pressure deficit, the driving force for transpiration, at humid

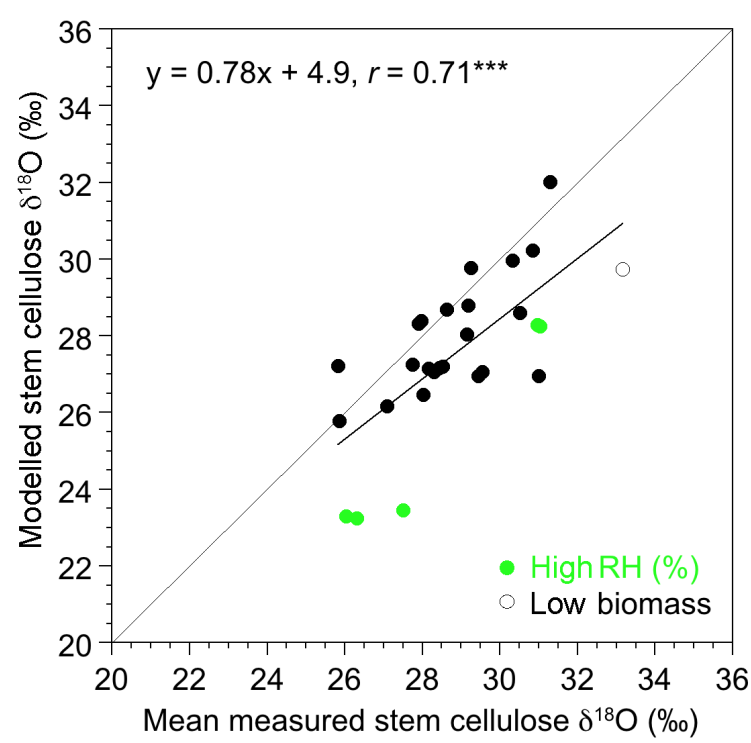

Figure 4. Comparison of simulated and measured stem cellulose $\delta^{18} \mathrm{O}$ for 31 sites in temperate and boreal forests (mainly in Europe). Each symbol represents the mean over the years 1960-2003 (or up to 2012 if available) for a specific species (e.g., Quercus petraea (Matt.) Liebl., Table S1) and the corresponding plant functional type in LPX-Bern. Sites where the relative humidity forcing has very high values $(>80 \%)$ are highlighted in light green. The open symbol reflects a single site (CAZ) where simulated above ground biomass is very low. See supplementary online material for location and description of sites (Table S1). Pearson's correlation coefficient $(r)$ and the significance level $\left({ }^{* * *} P<0.001\right)$ were calculated across all sites.

sites. At a single site (CAZ) where LPX-Bern simulates extremely low biomass of less than $30 \mathrm{~g} \mathrm{C} \mathrm{m}^{-2}$, because herbaceous plants dominate in this grid cell, stem cellulose $\delta^{18} \mathrm{O}$ is also underestimated (open symbol in Fig. 4). Excluding this site and the very humid sites yields a correlation coefficient of $r=0.65$, which is not higher than for all sites. We conclude that LPX-Bern is able to represent the magnitude and the spatial climatological pattern of $\delta^{18} \mathrm{O}$ in stem cellulose in Europe, generally within a few per mil of available observations.

This conclusion is further corroborated by comparing LPX-Bern results with $\delta^{18} \mathrm{O}$ data from two Swiss sites (LOV, LOT) for which detailed $\delta^{18} \mathrm{O}$ data are available for soil water, needle water, and stem wood (Table 1), but for a single year only. Simulated enrichment of needle water above soil water as well as simulated enrichment of stem cellulose above needle water is within the observed range at the two sites (Table 1). We note that this comparison is somewhat hampered by the large variability in the biweekly samples (e.g., for leaf water $\delta^{18} \mathrm{O}$ at LOV: $3.9-16.4 \%$ and at LOT: $-4.6-11.4 \%$ o) that LPX-Bern cannot reproduce because the model is driven by monthly data. 

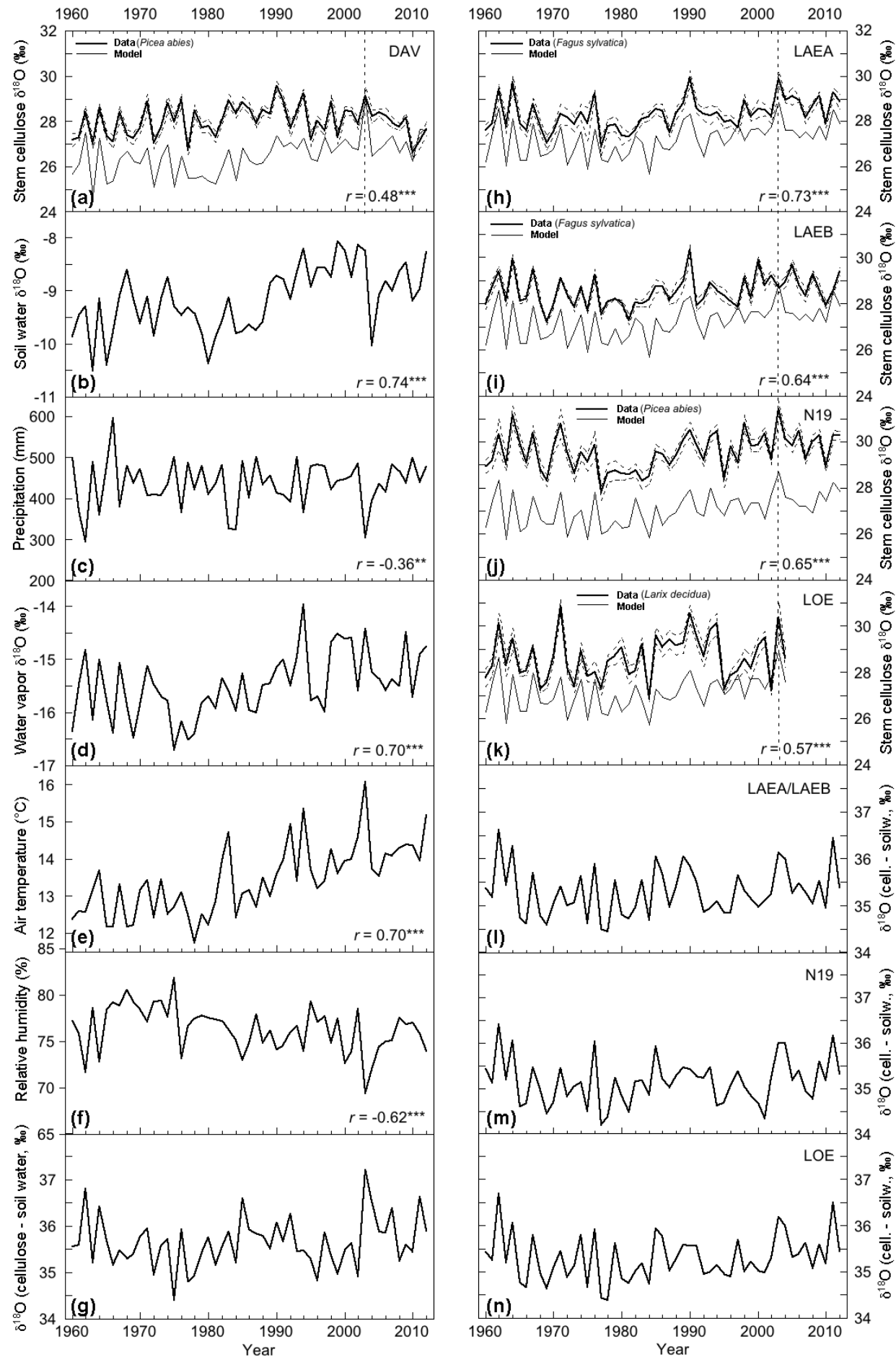

Figure 5. (a) Comparison of measured (data) and simulated (model) stem cellulose $\delta^{18} \mathrm{O}$ for the alpine site Davos (DAV), (h-k) for Lötschen Valley (N19, LOE) and sites Lägern (LAEA, LAEB) in the Swiss Central Plateau. Standard errors (dashed lines) are based on measurements of 10 trees. Panels (b-f) show input data as used for the simulation of stem cellulose $\delta^{18} \mathrm{O}$ in LPX-Bern for site DAV (average of June, July, and August is presented). The vertical dashed line highlights the extremely hot summer 2003. Pearson's correlation coefficients, $r$, with simulated stem cellulose $\delta^{18} \mathrm{O}$ are shown. Significance levels for the correlations are $\left({ }^{*} P<0.05 ;{ }^{* *} P<0.01,{ }^{* * *} P<0.001\right)$. Panels $(\mathrm{g})$ and (l-n) show the ${ }^{18} \mathrm{O}$-enrichment in stem cellulose above soil water $\delta^{18} \mathrm{O}$. Note that in LPX-Bern sites LAEA, LAEB, N19, and LOE lie within the same grid cell but are represented by different tree functional types (broad-leaved deciduous (LAEA, LAEB), needle-leaved evergreen (N19), and needle-leaved deciduous (LOE)). 
Table 1. Comparison of input data and simulations by LPX-Bern (Model) against measurements (observed) performed at two sites (LOV, LOT) in the Lötschen Valley (Switzerland) for averages across June, July, and August 2008. Because the two sites lie within the same grid cell of LPX-Bern, the simulated data are identical.

\begin{tabular}{lrrr}
\hline Parameter & \multicolumn{2}{c}{ Observed } & Model \\
& LOV & LOT & LPX-Bern \\
\hline Air temperature $\left({ }^{\circ} \mathrm{C}\right)$ & 15.4 & 11.1 & 16.5 \\
Relative humidity (\%) & 75.6 & 72.6 & 78.5 \\
Precipitation $(\mathrm{mm})$ & 251.5 & 294.8 & 387.0 \\
Soil water $\delta^{18} \mathrm{O}(\% \circ)$ & -6.1 & -8.6 & -7.8 \\
Needle water $\delta^{18} \mathrm{O}(\% \circ)$ & 10.6 & 3.0 & 6.5 \\
Stem cellulose $\delta^{18} \mathrm{O}(\% o)$ & 29.2 & 29.0 & 27.3 \\
Needle water - soil water $\delta^{18} \mathrm{O}(\% \circ)$ & 16.7 & 11.6 & 14.3 \\
Stem cellulose - needle water $\delta{ }^{18} \mathrm{O}(\% o)$ & 18.6 & 26.0 & 20.8 \\
Stem cellulose - soil water $\delta^{18} \mathrm{O}(\% \circ)$ & 35.3 & 37.6 & 35.1 \\
\hline
\end{tabular}

The interannual variability and decadal-scale trends of stem cellulose $\delta^{18} \mathrm{O}$ are analyzed for five tree ring sites in Switzerland and for the period 1960 to 2012 for which temporally resolved input data from ECHAM5-JSBACH are available (Fig. 5). Due to the coarse spatial resolution of the gridded LPX-Bern version applied here, all sites except DAV lie within the same grid cell and model results are almost identical. Slight differences in the model time series shown in Fig. 5 are due to differences in tree functional types (LAEA/LAEB: deciduous broad-leaved, N19: evergreen needle-leaved, LOE: deciduous needle-leaved; thin lines in Fig. 5h-k) selected for the comparison with the tree ring $\delta^{18} \mathrm{O}$ data.

The simulated stem cellulose $\delta^{18} \mathrm{O}$ time series capture the measured evolution and interannual variability (Fig. 5a, h-k). Based on visual comparison, the correlation between simulated and measured stem cellulose $\delta^{18} \mathrm{O}$ is best in the 1960s and early 1970s and is weaker thereafter. Model values increase after 1990, probably due to higher temperature and soil water $\delta^{18} \mathrm{O}$, which is not recognized in the tree ring data. For the entire time series, the correlations range between 0.48 and 0.73 , with the highest value at LAEA in the Swiss Central Plateau (Fig. 5h) and the lowest value at the alpine site DAV (Fig. 5a). The correlation coefficients are comparable to the correlations between the four tree ring series in the Swiss Central Plateau (LAEA, LAEB) and the Lötschen Valley (N19, LOE), which range between 0.55 and 0.82 . In other words, the correlation between measured and modeled grid cell values reflects site-to-site variability within the grid cell. In conclusion, not only the reconstructed climatological mean pattern across Europe, but also the reconstructed temporal variability in stem cellulose $\delta^{18} \mathrm{O}$ at individual Swiss sites is generally well represented by LPX-Bern.

An extreme heatwave hit Europe in 2003 (Figs. 5, 7, S2, and S3) with summer temperatures of $3{ }^{\circ} \mathrm{C}$ above the 1961 to 1990 mean (Schär et al., 2004). Thus, one expects to find extreme values in $\delta^{18} \mathrm{O}$. Indeed, simulated stem cellulose $\delta^{18} \mathrm{O}$ peaks in this year with record or near-record high values for the analysis period (Fig. 5). Very low humidity and high air temperatures most likely lead to strong leaf water $\delta^{18} \mathrm{O}$ enrichment. Surprisingly, the response in $\delta^{18} \mathrm{O}$ in the tree ring data is different for different sites. Measurements at LAEA, $\mathrm{N} 19$, and LOE show a strong peak in $\delta^{18} \mathrm{O}$ (Fig. 5h, j, k), DAV a small peak (Fig. 5a), and site LAEB even lower values than during the previous and following year (Fig. 5i). Apparently, local differences in environmental conditions or different reactions of tree species may mask the expected drought signal in stem cellulose $\delta^{18} \mathrm{O}$. A well-known phenomenon is that extreme conditions may not be captured because growth is stopped, and the signal is therefore not recorded (Sarris et al., 2013).

\subsection{Sensitivity analysis to explore the influence of individual drivers}

Simulated variability in stem cellulose $\delta^{18} \mathrm{O}$ arises from various drivers and their influence is quantified within LPXBern. In the standard simulation with the combination of all drivers, air temperature, soil water $\delta^{18} \mathrm{O}$, and water vapor $\delta^{18} \mathrm{O}$ are positively correlated with cellulose $\delta^{18} \mathrm{O}$ as demonstrated for site DAV (Fig. 5b, d, e). In contrast, relative humidity and precipitation are negatively correlated with cellulose $\delta^{18} \mathrm{O}$ (Fig. 5c, f). The correlation is strongest with soil water $\delta^{18} \mathrm{O}$, suggesting a high dependence of our results on the isotope input data.

The influence of various drivers on stem cellulose $\delta^{18} \mathrm{O}$ is further investigated in transient factorial simulations where individual drivers were kept at their climatological mean values representative for the early 20th century for the meteorological variables temperature, precipitation, cloud cover, and number of wet days, and 1960 values for relative humidity, $\delta^{18} \mathrm{O}$ soil water, and water vapor input data. The results (Fig. 6) show that, in order of importance, variations in relative humidity, temperature, $\delta^{18} \mathrm{O}$ in soil water, and water vapor $\delta^{18} \mathrm{O}$ force decadal-scale and interannual variability in 
Table 2. Effect of a $10 \%$ increase in parameter values/input data on simulated stem cellulose $\delta^{18} \mathrm{O}$ at site DAV for the June, July, and August 1960 average.

\begin{tabular}{lr}
\hline Parameter & $\begin{array}{r}\text { Change in } \\
\end{array}$ \\
\hline Air temperature $\left({ }^{\circ} \mathrm{C}\right)$ & -0.2 \\
Relative humidity & -6.7 \\
$\varepsilon_{\mathrm{k}}$ & 1.7 \\
$\varepsilon^{+}$ & 2.3 \\
Transpiration $(E)$ & -0.3 \\
Path length $(L)$ & -0.3 \\
Péclet number $(\wp)$ & -0.3 \\
$p_{\mathrm{ex}}$ & -1.9 \\
$\delta^{18} \mathrm{O}_{\mathrm{sw}}$ & 2.4 \\
$\delta^{18} \mathrm{O}_{\mathrm{wv}}$ & 2.9 \\
\hline
\end{tabular}

cellulose $\delta^{18} \mathrm{O}$. The simple sensitivity analysis for the site DAV, where input data or parameters were increased by $10 \%$, also reveals that stem cellulose $\delta^{18} \mathrm{O}$ is sensitive to changes in relative humidity, soil water, and water vapor $\delta^{18} \mathrm{O}$ (Table 2). Precipitation had no influence on stem cellulose $\delta^{18} \mathrm{O}$ in the transient simulation (Fig. 6a). In contrast, accounting for the Péclet effect resulted in consistently lower values with nearly no influence on interannual variation (Fig. 6b). Atmospheric $\mathrm{CO}_{2}$ had a very minor effect on cellulose $\delta^{18} \mathrm{O}(<0.04 \%$ oxcept for a single year with an effect of $-0.18 \%$ ), while $\mathrm{N}$ deposition had no influence (Fig. 6b). In years when relative humidity and temperature had a positive effect, the combined effect of temperature, precipitation, number of wet days, and cloud cover (termed "clim effect" in Fig. 6a) was often large and also positive. In years when the influence of relative humidity and temperature had opposing signs, the clim effect was around zero. The 20th century trends in air temperature mostly led to higher stem cellulose $\delta^{18} \mathrm{O}$ during the last 5 decades compared to the early 20th century. The clim effect leads to slightly higher decadal-averaged values in stem cellulose $\delta^{18} \mathrm{O}(+0-2 \% \circ)$ towards the end of the simulation. However, these values are not unusual in the context of the decadal variability simulated for the past 5 decades.

Sensitivities of cellulose $\delta^{18} \mathrm{O}$ to the input data are similar at all sites (Fig. 6c-e). Compared to DAV, the magnitude of the decadal-scale trends induced by climate and soil water $\delta^{18} \mathrm{O}$, is somewhat smaller at other sites. Conversely, changes in relative humidity have a stronger influence at LAEB and N19. At all sites, the prescribed changes in relative humidity (i.e., keeping values at mean representative for the early 20th century) cause on average lower cellulose $\delta^{18} \mathrm{O}$ during the 1980s than compared to the end of the simulation. Decadalscale variability is also related to changes in soil water $\delta^{18} \mathrm{O}$. In particular, soil water $\delta^{18} \mathrm{O}$ variations caused an increase in stem cellulose $\delta^{18} \mathrm{O}$ of about 0.3 to $0.5 \%$ in the $1980 \mathrm{~s}$ that persisted thereafter (Fig. 6e). A similar trend was simulated for climate, but with more variability between sites. At N19

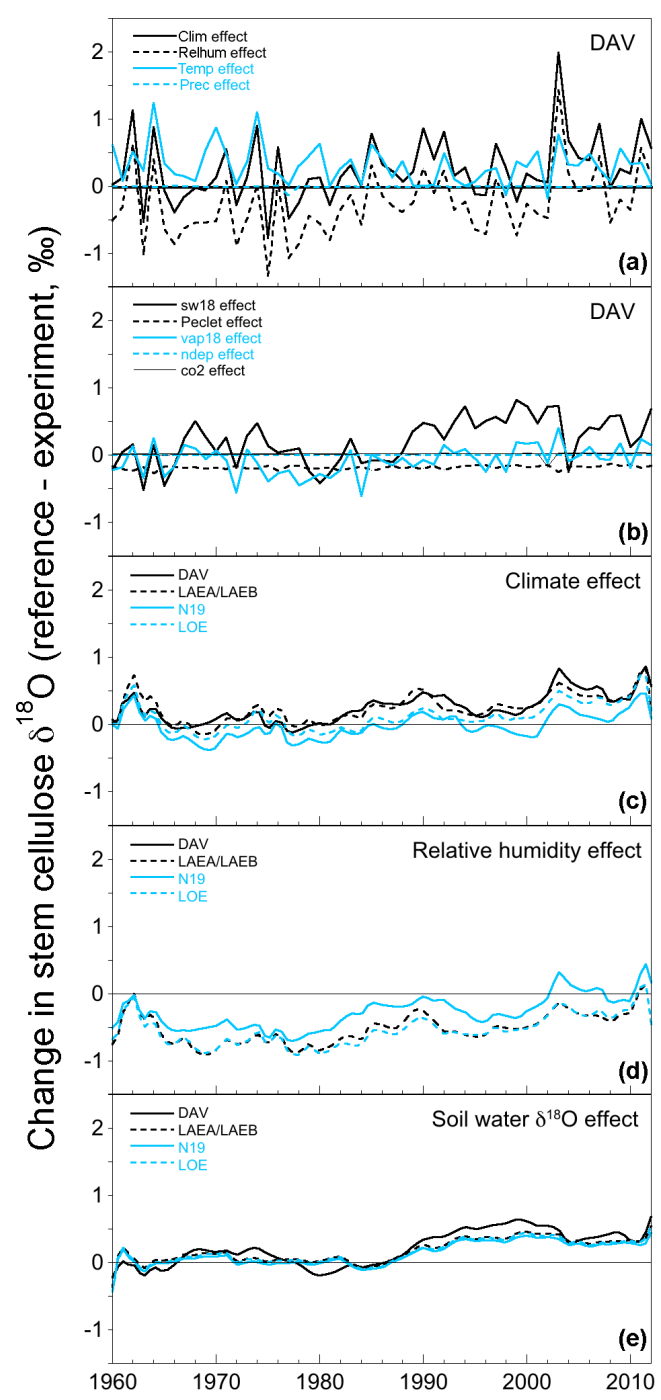

Figure 6. Influence of forcing factors and the Péclet parameterization on simulated $\delta^{18} \mathrm{O}$ of stem cellulose. Panels (a) and (b) show results for the alpine site in Davos (DAV) and for all factors investigated. Panels (c), (d) and (e) each show the influence of one individual major driver for five sites, located within the Swiss Central Plateau (Lägeren; LAEA and LAEB, dashed black line), and the high-elevation sites in the Lötschen Valley (N19, solid blue; LOE, dashed blue) and in Davos (DAV, black solid). Each curve shows the differences in $\delta^{18} \mathrm{O}$ of stem cellulose between the reference simulation (all forcings vary) and one sensitivity simulation (one forcing factor is kept constant). Constant forcing factors include relative humidity (relhum effect), air temperature (temp effect), precipitation (prec effect), soil water $\delta^{18} \mathrm{O}$ (sw18 effect), water vapor $\delta^{18} \mathrm{O}$ (vap18 effect), atmospheric nitrogen deposition (ndep effect), atmospheric $\mathrm{CO}_{2}\left(\mathrm{CO}_{2}\right.$ effect)) or a combination of constant forcings (climate (clim effect), i.e., temperature, precipitation, cloud cover, and number of wet days). An additional simulation is run without the Péclet effect (Peclet effect). The curves are smoothed with Stineman functions in (c), (d), and (e). 


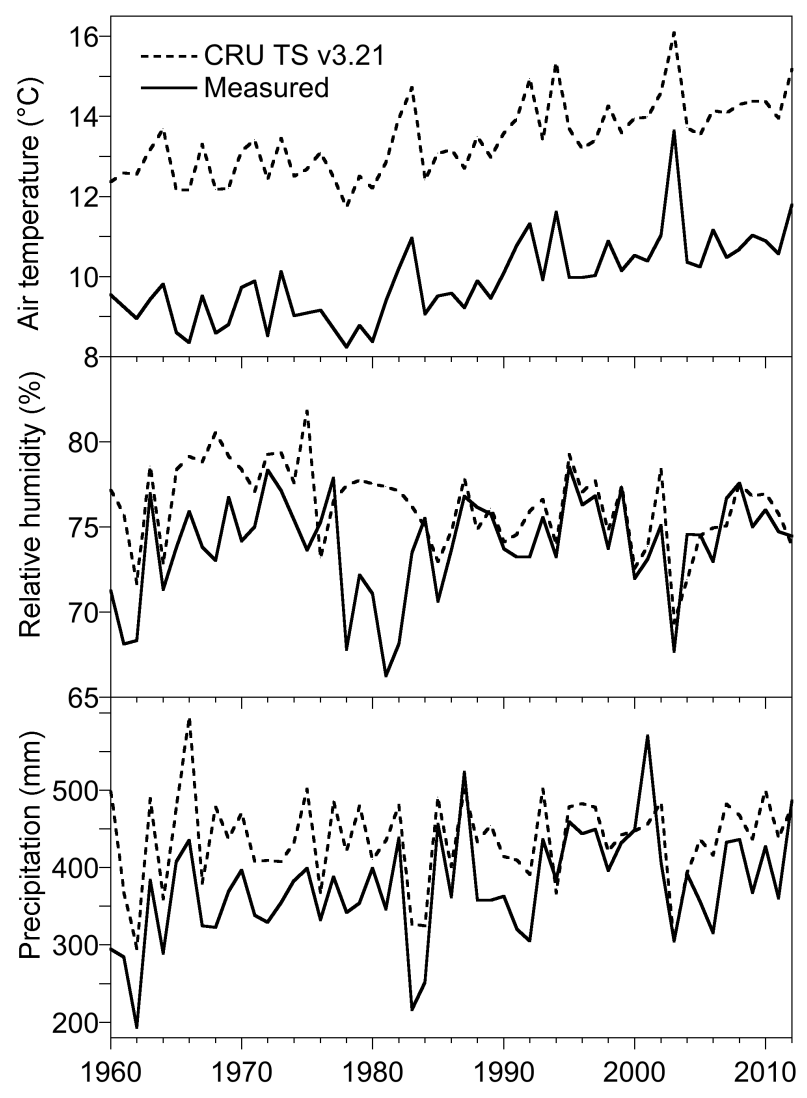

Figure 7. Comparison of climate input data for the alpine site Davos (DAV). Solid lines show grid cell average data from the CRU climatology (CRU TS v3.21) as used in our standard model setup. Dashed lines show data from a nearby meteorological station as used in a sensitivity simulation (run ewcTmeteo in Fig. 8). Temperature is warmer and precipitation higher in the grid cell average data compared to the local data.

the climate effect was always lowest and there was no clear trend. In brief, LPX-Bern simulates substantial interannual and decadal-scale variability in stem cellulose $\delta^{18} \mathrm{O}$ which is attributable to variability in relative humidity, temperature, and $\delta^{18} \mathrm{O}$ in soil water and vapor.

West et al. (2008) assumed that leaf temperature exceeds air temperature by $5{ }^{\circ} \mathrm{C}$ in their implementation of the Craig-Gordon model. Since CRU air temperatures are on average $3.5^{\circ} \mathrm{C}$ higher than measured temperatures for the Swiss site DAV (Fig. 7), we did not want to further increase them. Instead we tested the effect of reducing leaf temperature by $3.5^{\circ} \mathrm{C}$ compared to air temperature, which improved the correlation of simulated and measured stem cellulose $\delta^{18} \mathrm{O}$ at DAV and increased the simulated stem cellulose $\delta^{18} \mathrm{O}$ compared to the original simulation (Fig. 8, Tleaf vs. LPX-Bern standard simulation: $27.05 \%$ vs. $26.47 \%$ o (average for 1960-2012)). Similarly, accounting for a temperature-dependent biochemical fractionation (ewcT) led to consistently higher cellulose $\delta^{18} \mathrm{O}(27.21 \%$ )

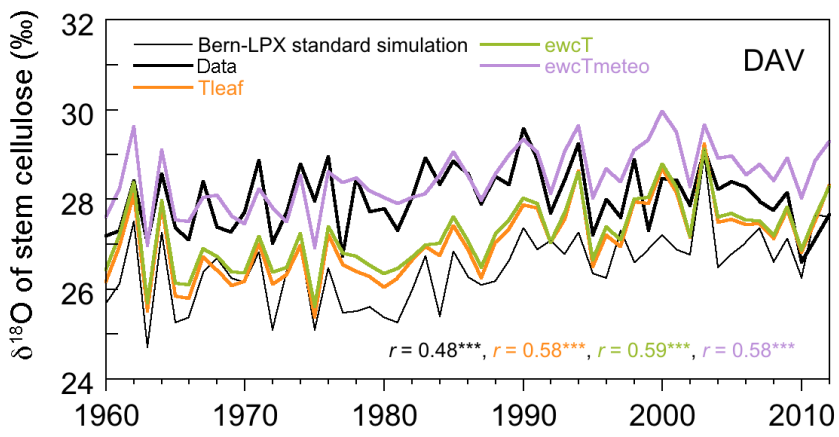

Figure 8. Effect of reduced leaf temperature and a temperaturedependent biochemical fraction $\left(\varepsilon_{\mathrm{wc}}\right)$ on simulated stem cellulose $\delta^{18} \mathrm{O}$ for site DAV (Davos). Leaf temperature was decreased by $3.5^{\circ} \mathrm{C}$ relative to air temperature (Tleaf) because at site DAV, measured air temperature was on average $3.5^{\circ} \mathrm{C}$ lower than temperature from CRU TS v.3.21 used in the model (LPX-Bern standard simulation). The temperature-dependent biochemical fraction was tested with the air temperature from CRU (ewcT) and with measured air temperature from a nearby meteorological station (ewcTmeteo). Pearson's correlation coefficients, $r$, with measured stem cellulose $\delta^{18} \mathrm{O}$ are shown. Significance levels for the correlations are (* $P<0.05$; ** $P<0.01$; *** $P<0.001)$.

compared to the standard simulation, with a nearly identical correlation coefficient compared to the Tleaf simulation. When the temperature-dependent formulation for $\varepsilon_{\mathrm{wc}}$ was combined with the temperature forcing from a nearby meteorological station (ewcTmeteo), stem cellulose $\delta^{18} \mathrm{O}$ increased further and was even slightly higher than the measured data (28.47\%o vs. $28.02 \%$, average for $1960-2012$ ). The correlation remained equally good compared to the simulation with a temperature-dependent $\varepsilon_{\mathrm{wc}}$ and CRU climate. We also evaluated temporal mean stem cellulose across all (European) sites. Compared to the original simulations (Fig. 4), the correlation between modeled and measured data was slightly lower if $\varepsilon_{\mathrm{wc}}$ was allowed to depend on temperature ( $r=0.68$ vs. $r=0.71$, data not shown). Since we know that the CRU temperatures are too low for some sites (e.g., Fig. 7), we performed an additional test where we set $\varepsilon_{\mathrm{wc}}$ to $31 \%$ to mimic the effect of low growth temperatures on biochemical fractionation. This test should improve results for cool sites (INA, GUT, ILO, CAV), which was indeed what we observed. For these sites the model-observation differences decreased (results not shown), while for sites with high mean annual temperatures (e.g., REN, LIL) LPX-Bern overestimated stem cellulose $\delta^{18} \mathrm{O}$ or left them unchanged.

\section{Discussion and conclusion}

Formulations to describe $\delta^{18} \mathrm{O}$ in leaf water and stem cellulose are implemented in the LPX-Bern DGVM and a compilation of tree ring data of $\delta^{18} \mathrm{O}$ in stem cellulose, mainly for Europe, is established. This allows us to model the large- 
scale distribution of leaf water and stem cellulose $\delta^{18} \mathrm{O}$ on the global scale, study spatiotemporal variability in $\delta^{18} \mathrm{O}$, evaluate model formulations describing the transfer of $\delta^{18} \mathrm{O}$ signals within plants, and, last but not least, investigate underlying drivers and processes. Further, the model permits us to address how interannual, decadal and 20th century changes in climate and environmental variables may have affected $\delta^{18} \mathrm{O}$ in stem cellulose, thereby contributing to the interpretation of tree ring $\delta^{18} \mathrm{O}$ data.

The comparison of 50-year-averaged model results with tree ring data, mainly across Europe, shows that the largescale climatological-mean pattern in stem cellulose $\delta^{18} \mathrm{O}$ is well captured by the model (Fig. 4). The high correlation between modeled time series and $\delta^{18} \mathrm{O}$ tree ring data from five sites in Switzerland suggests that the interannual variability in stem cellulose $\delta^{18} \mathrm{O}$ is also well represented by LPX-Bern (Fig. 5). Thus, the formulations describing water uptake by plants and transpiration, regulated by stomatal conductance and influenced by ambient $\mathrm{CO}_{2}$ concentrations, and corresponding isotope fractionations appear consistent with tree ring $\delta^{18} \mathrm{O}$ data. In an earlier study (Saurer et al., 2014), it is shown that LPX-Bern is also able to represent the spatial gradients in $\delta^{13} \mathrm{C}$, the temporal change in $\delta^{13} \mathrm{C}$ and intrinsic water use efficiency over the 20th century as reconstructed from a European-wide tree ring network. The good agreement with tree ring data suggests that LPX-Bern is suited to explore the $\delta^{18} \mathrm{O}$ signal transfer within forest ecosystems and to study the relationship between $\delta^{18} \mathrm{O}$ in stem cellulose and meteorological drivers in a mechanistic way, at least within European boreal and temperate forests. This aspect may become particularly relevant in the context of global warming, with more extreme conditions, including heatwaves and droughts, expected. The model could be used in future work in connection with tree ring data of growth, $\delta^{13} \mathrm{C}$, and $\delta^{18} \mathrm{O}$ to study the nexus between flows of water (governing evaporative cooling and runoff) and $\mathrm{C}$ as well as $\mathrm{C}$ sequestration. In general, we expect any changes in seasonality that could potentially affect soil water $\delta^{18} \mathrm{O}$ such as earlier snow melt to be translated to stem cellulose $\delta^{18} \mathrm{O}$ in LPX-Bern.

Interannual variability and decadal-scale trends of modeled tree ring $\delta^{18} \mathrm{O}$ in Switzerland are predominantly driven by the meteorological variables relative humidity and temperature and the variability in soil water and water vapor $\delta^{18} \mathrm{O}$ (Fig. 6, Table 2). In contrast, $\mathrm{N}$ deposition or increasing $\mathrm{CO}_{2}$ leading to $\mathrm{CO}_{2}$ fertilization within LPX-Bern do not influence trends and variability in stem cellulose $\delta^{18} \mathrm{O}$ at the investigated sites. This is a novel finding that is important for tree ring $\delta^{18} \mathrm{O}$ interpretation, and contrasts with respective findings for $\delta^{13} \mathrm{C}$, where $\mathrm{CO}_{2}$ is an important factor (Saurer et al., 2014). A strong influence of relative humidity and soil water on stem cellulose $\delta^{18} \mathrm{O}$ is consistent with expectations from isotope theory (McCarroll and Loader, 2004). This is also in agreement with many tree ring studies that found a significant effect of relative humidity (Burk and Stuiver, 1981), vapor pressure differences (Kahmen et al., 2011), and $\delta^{18} \mathrm{O}$ of precipitation (Waterhouse et al., 2002) based on statistical analyses. Precipitation variations in our study did not influence interannual variability nor long-term trends in stem cellulose $\delta^{18} \mathrm{O}$ in factorial simulations where precipitation is kept constant at climatological mean values. Hence, it seems unlikely that $\delta^{18} \mathrm{O}$ as simulated by LPX-Bern will capture changes in precipitation patterns that are not associated with changes in isotope signals. Nevertheless, time series of precipitation at DAV are correlated with modeled time series of $\delta^{18} \mathrm{O}$ in stem cellulose (Fig. 5c) in agreement with observations (e.g., Reynolds-Henne et al., 2007; Rinne et al., 2013; Hartl-Meier et al., 2015), albeit less than correlations for soil water and vapor $\delta^{18} \mathrm{O}$ (Fig. 5b, d), air temperature, and humidity (Fig. 5e, f). This correlation likely arises from the impact of precipitation on other variables, e.g., relative humidity, and from the correlation of precipitation with other driving variables. There is clearly decadal variability in simulated stem cellulose $\delta^{18} \mathrm{O}$ linked to variability in $\delta^{18} \mathrm{O}$ and climate input data; e.g., the effect of soil water $\delta^{18} \mathrm{O}$ varied around zero in the 1960s and is consistently positive in the 1990s (Fig. 6e).The identification of potential century-scale trends is hampered by the lack of suitable input data for relative humidity and $\delta^{18} \mathrm{O}$ of soil water and water vapor in this study.

There are several sources of uncertainty that may explain the remaining deviations between simulated and measured stem cellulose $\delta^{18} \mathrm{O}$ for the Swiss and European sites. First, we run the model at a coarse spatial resolution (about $220 \mathrm{~km} \times 320 \mathrm{~km}$ in southern Europe) and local site conditions are expected to be different from grid cell average conditions. Climate input data and prescribed $\delta^{18} \mathrm{O}$ in soil water and water vapor therefore only approximate local values at the site. Sensitivity simulations (Table 2 ) and a comparison of soil water $\delta^{18} \mathrm{O}$ with the $\delta^{18} \mathrm{O}$ from the GNIP precipitation network reveal that uncertainties in the input data can indeed well explain deviations between modeled and measured $\delta^{18} \mathrm{O}$ in stem cellulose. Uncertainties in relative humidity appear particularly relevant and are likely at the origin of relatively large data-model discrepancies at humid sites. Only modest changes in humidity, and thus water pressure deficit, do result in significant changes in stem cellulose $\delta^{18} \mathrm{O}$. Daily variations and within-canopy variations in humidity (and other variables) are not taken into account in our approach. Second, we assume that parameters such as the fractionation between water and cellulose, $\varepsilon_{\mathrm{wc}}$, the path length, $L$, for the Péclet effect or the proportion of carbonyl oxygen exchange with source water, $p_{\mathrm{ex}}$, are constant, although they may vary (e.g., Wang et al., 1998; Ripullone et al., 2008; Sternberg and Ellsworth, 2011; Song et al., 2014). The biochemical fractionation factor $\varepsilon_{\mathrm{wc}}$ is commonly assumed to be $27 \%$. Only recently Sternberg and Ellsworth (2011) suggested that $\varepsilon_{\mathrm{wc}}$ increases up to about $31 \%$ at low growth temperatures of $5{ }^{\circ} \mathrm{C}$. However, their experiments were performed in a rather artificial system as they studied wheat seedlings cultivated in the dark and their findings are controversially dis- 
cussed (Sternberg, 2014; Zech et al., 2014). Application of a temperature-dependent $\varepsilon_{\mathrm{wc}}$ in LPX-Bern in combination with meteorological data from a nearby weather station removed the model measurement offset for the alpine site DAV and improved the model measurement correlation compared to the standard setup. So far our results seem the first to indicate that a temperature-dependent $\varepsilon_{\mathrm{wc}}$ might perhaps also be relevant under field conditions. Yet, uncertainties in other input data and model structure are too large to draw any firm conclusions. The path length $(L)$ of $0.03 \mathrm{~m}$ for the Péclet number agrees with previous studies (Wang et al., 1998; Gessler et al., 2013), although large variability has been reported (Kahmen et al., 2009). Also the proportion of carbonyl oxygen exchange with source water $\left(p_{\text {ex }}\right)$ of 0.4 seems reasonable compared with published values (Cernusak et al., 2005; Gessler et al., 2009, 2013; Song et al., 2014). However, relatively small changes in $p_{\text {ex }}$ have a significant impact on $\delta^{18} \mathrm{O}$ in stem cellulose (Table 2) and recent studies suggest this value could range between 0.2 and 0.42 (Gessler et al., 2009; Song et al., 2014). Third, in LPX-Bern, photoassimilates are allocated to growing tissues instantaneously and are not stored, e.g., as starch. The simulated tree ring $\delta^{18} \mathrm{O}$ is therefore exclusively affected by the current year's meteorology, and not by that of previous years.

The fact that soil water $\delta^{18} \mathrm{O}$ has a strong effect on stem cellulose $\delta^{18} \mathrm{O}$ calls for a very careful evaluation of the source water input data. Unfortunately oxygen isotope ratios of soil water are not systematically measured as is the case for precipitation (Global Network for Isotopes in Precipitation, The GNIP Database, http://www.iaea.org/water). However, the comparison of the soil water $\delta^{18} \mathrm{O}$ data from the ECHAM5-JSBACH model as used as input to LPX-Bern with the GNIP data reveal a good agreement, and deviations in $\delta^{18} \mathrm{O}$ between ECHAM5-JSBACH soil water and GNIP precipitation $\delta^{18} \mathrm{O}$ data are generally less than $2 \%$ (Haese et al., 2013).

Our leaf water $\delta^{18} \mathrm{O}$ results provide another global-scale estimate of leaf water $\delta^{18} \mathrm{O}$ in addition to the GIS-based approach by West et al. (2008). There are several possible factors that could explain why leaf water $\delta^{18} \mathrm{O}$ simulated by LPX-Bern was mostly higher compared to simulations by West et al. (2008) (Fig. 2). Firstly, the $\delta^{18} \mathrm{O}$ input data and relative humidity forcings were not the same. West and colleagues used annually averaged $\delta^{18} \mathrm{O}$ from the GNIP precipitation network, which obviously provides lower values than when summer $\delta^{18} \mathrm{O}$ would have been used. The mechanistic approach implemented in LPX-Bern considers seasonally varying $\delta^{18} \mathrm{O}$ of both source water and atmospheric water vapor, and models explicitly daily stomatal conductance, transpiration, and associated $\delta^{18} \mathrm{O}$ transport. Secondly, West et al. (2008) assumed that leaf temperature is $5^{\circ} \mathrm{C}$ higher than air temperature. Observations support this for broad-leaved, but less so for needle-leaved species (Leuzinger and Körner, 2007). Because sites with conifers dominate our observational data set, it is reasonable to assume that leaf temper- ature equals air temperature in our study. We only have few measurements to support this and more field data would be needed for a meaningful evaluation of simulated leaf water $\delta^{18} \mathrm{O}$. Nevertheless, the LPX-Bern simulated mean value of leaf water $\delta^{18} \mathrm{O}$ for one grid cell is within the range of the mean values measured at two sites in this grid cell (Table 1). Additionally, the good agreement between measured and modeled stem cellulose $\delta^{18} \mathrm{O}$ in Europe appears to implicitly support the LPX-Bern estimates in leaf water $\delta^{18} \mathrm{O}$ for this region.

We implemented routines to simulate leaf water and stem cellulose $\delta^{18} \mathrm{O}$ in the LPX-Bern DGVM and successfully modeled the spatiotemporal variability in $\delta^{18} \mathrm{O}$ as revealed by European tree ring data. As tree ring isotope networks are becoming more widespread, the ${ }^{18} \mathrm{O}$-enabled LPX-Bern model provides an ideal tool to explore large-scale spatial and temporal patterns in cellulose $\delta^{18} \mathrm{O}$ and to help unravel underlying processes and drivers.

\section{Data availability}

Part of the measured tree ring $\delta^{18} \mathrm{O}$ data presented in this study are available from http://www.ncdc.noaa.gov/paleo/ treering/isotope/tree-isotope.html. Data from Swiss sites that have not been previously published cannot be made available yet, as $\mathrm{PhD}$ students are working on other publications that rely on these data. For access to data presented in Treydte et al. 2007 and Kress et al. 2010, the authors should be contacted personally. Stem cellulose and leaf water $\delta^{18} \mathrm{O}$ simulated with LPX-Bern, will be made available on http: $/ / w w w . c l i m a t e . u n i b e . c h / ? L 1=$ research $\& L 2=r c a r \& L 3=l p x$.

\section{The Supplement related to this article is available online at doi:10.5194/bg-13-3869-2016-supplement.}

Acknowledgements. We thank Martin Werner for providing the soil water and humidity $\delta^{18} \mathrm{O}$ data from the ECHAM5-JSBACH model, and Kerstin Treydte for sharing data from two of the Lötschen Valley sites. Jason West is acknowledged for providing the leaf water $\delta^{18} \mathrm{O}$ data and Ansgar Kahmen for sharing his offline model. We thank Rolf Siegwolf for his valuable input and Raphael Roth for support during model development. Measurements from weather stations are from MeteoSwiss, the Swiss Federal Office of Meteorology and Climatology. This study is supported by the Swiss National Science Foundation (SNF) through the Sinergia Project iTREE (CRSII3_136295) and the grant to the Division of Climate and Environmental Physics (200020-14174).

Edited by: X. Wang 


\section{References}

An, W., Liu, X., Leavitt, S. W., Xu, G., Zeng, X., Wang, W., Qin, D., and Ren, J.: Relative humidity history on the Batang-Litang Plateau of western China since 1755 reconstructed from tree-ring $\delta^{18} \mathrm{O}$ and $\delta \mathrm{D}$, Clim. Dynam., 42, 2639-2654, 2014.

Anderson, W. T., Bernasconi, S. M., McKenzie, J. A., and Saurer, M.: Oxygen and carbon isotopic record of climatic variability in tree ring cellulose (Picea abies): An example from central Switzerland (1913-1995), J. Geophys. Res.-Atmos., 103, 31625-31636, 1998.

Babst, F., Alexander, M. R., Szejner, P., Bouriaud, O., Klesse, S., Roden, J., Ciais, P., Poulter, B., Frank, D., Moore, D. J. P., and Trouet, V.: A tree-ring perspective on the terrestrial carbon cycle, Oecologia, 176, 307-322, 2014.

Barbour, M. M.: Stable oxygen isotope composition of plant tissue: a review, Funct. Plant Biol., 34, 83-94, 2007.

Barbour, M. M. and Farquhar, G. D.: Relative humidity- and ABAinduced variation in carbon and oxygen isotope ratios of cotton leaves, Plant Cell Environ., 23, 473-485, 2000.

Barbour, M. M., Roden, J. S., Farquhar, G. D., and Ehleringer, J. R.: Expressing leaf water and cellulose oxygen isotope ratios as enrichment above source water reveals evidence of a Péclet effect, Oecologia, 138, 426-435, 2004.

Begert, M., Schlegel, T., and Kirchhofer, W.: Homogeneous temperature and precipitation series of Switzerland from 1864 to 2000, Int. J. Climatol., 25, 65-80, 2005.

Bottinga, Y. and Craig, H.: Oxygen isotope fractionation between $\mathrm{CO}_{2}$ and water and isotopic composition of marine atmospheric $\mathrm{CO}_{2}$, Earth Planet. Sc. Lett., 5, 285-295, 1969.

Bowen, G. J. and Revenaugh, J.: Interpolating the isotopic composition of modern meteoric precipitation, Water Resour. Res., 39, 1299, doi:10.1029/2003WR002086, 2003.

Burk, R. L. and Stuiver, M.: Oxygen isotope ratios in trees reflect mean annual temperature and humidity, Science, 211, 14171419, 1981.

Cappa, C. D., Hendricks, M. B., DePaolo, D. J., and Cohen, R. C.: Isotopic fractionation of water during evaporation, J. Geophys. Res.-Atmos., 108, 1-10, 2003.

Cernusak, L. A., Farquhar, G. D., and Pate, J. S.: Environmental and physiological controls over oxygen and carbon isotope composition of Tasmanian blue gum, Eucalyptus globulus, Tree Physiol., 25, 129-146, 2005.

Collatz, G. J., Ball, J. T., Grivet, C., and Berry, J. A.: Physiological and environmental regulation of stomatal conductance, photosynthesis and transpiration - A model that includes a laminar boundary layer, Agr. and Forest Meteorol., 54, 107-136, 1991.

Collatz, G. J., Ribas-Carbo, M., and Berry, J. A.: Coupled photosynthesis-stomatal conductance model for leaves of $\mathrm{C}_{4}$ plants, Aust. J. Plant Physiol., 19, 519-538, 1992.

Craig, H. and Gordon, L.: Deuterium and oxygen 18 variations in the ocean and the marine atmosphere, Consiglio Nazionale delle Ricerche, Laboratorio di Geologia Nucleare, Pisa, 1965.

Cuntz, M., Ogée, J., Farquhar, G. D., Peylin, P., and Cernusak, L. A.: Modelling advection and diffusion of water isotopologues in leaves, Plant Cell Environ., 30, 892-909, 2007.

Dansgaard, W.: Stable isotopes in precipitation, Tellus A, 16, doi:10.3402/tellusa.v16i4.8993, online first, 1964.
Dongmann, G., Nürnberg, H. W., Förstel, H., and Wagener, K.: On the enrichment of $\mathrm{H}_{2}^{18} \mathrm{O}$ in the leaves of transpiring plants, Radiat. Environ. Bioph., 11, 41-52, 1974.

Dunbar, R. B., Wellington, G. M., Colgan, M. W., and Glynn, P. W.: Eastern Pacific sea-surface temperature since 1600 A.D.: The $\delta^{18} \mathrm{O}$ record of climate variability in Galápagos corals, Paleoceanography, 9, 291-315, 1994.

Edwards, T. W. D., Birks, S. J., Luckman, B. H., and MacDonald, G. M.: Climatic and hydrologic variability during the past millennium in the eastern Rocky Mountains and northern Great Plains of western Canada, Quaternary Res., 70, 188-197, 2008.

Elderfield, $\mathrm{H}$. and Ganssen, G.: Past temperature and $\delta^{18} \mathrm{O}$ of surface ocean waters inferred from foraminiferal $\mathrm{Mg} / \mathrm{Ca}$ ratios, Nature, 405, 442-445, 2000.

Epstein, S., Thompson, P., and Yapp, C. J.: Oxygen and hydrogen isotopic ratios in plant cellulose, Science, 198, 1209-1215, 1977.

Etheridge, D. M., Steele, L. P., Langenfelds, R. L., Francey, R. J., Barnola, J. M., and Morgan, V. I.: Historical $\mathrm{CO}_{2}$ records from the Law Dome DE08, DE08-2, and DSS ice cores, in: Trends: A Compendium of Data on Global Change. Carbon Dioxide Information Analysis Center, Oak Ridge National Laboratory, US Department of Energy http://cdiac.ornl.gov/trends/co2/lawdome. html, Oak Ridge, Tenn., USA, 1998.

Farquhar, G. D., von Caemmerer, S., and Berry, J. A.: A biochemical model of photosynthetic $\mathrm{CO}_{2}$ assimilation in leaves of $\mathrm{C}_{3}$ species, Planta, 149, 78-90, 1980.

Farquhar, G. D. and Gan, K. S.: On the progressive enrichment of the oxygen isotopic composition of water along a leaf, Plant Cell Environ., 26, 1579-1597, 2003.

Farquhar, G. D. and Lloyd, J.: Carbon and oxygen isotope effects in the exchange of carbon dioxide between terrestrial plants and the atmosphere, in: Stable isotopes and plant carbon-water relations, edited by: Ehleringer, J. R., Hall, A. E., and Farquhar, G. D., Academic Press, San Diego, 47-70, 1993.

Farquhar, G. D. and von Caemmerer, S.: Modelling of photosynthetic response to environmental conditions, in: Physiological Plant Ecology II: Water Relations and Carbon Assimilation, edited by: Nobel, P. S., Osmond, C. B., and Ziegler, H., Spriner, Berlin, 549-587, 1982.

Ferrio, J. P. and Voltas, J.: Carbon and oxygen isotope ratios in wood constituents of Pinus halepensis as indicators of precipitation, temperature and vapour pressure deficit, Tellus B, 57, 164-173, 2005.

Flanagan, L. B., Comstock, J. P., and Ehleringer, J. R.: Comparison of Modeled and Observed Environmental Influences on the Stable Oxygen and Hydrogen Isotope Composition of Leaf Water in Phaseolus vulgaris L., Plant Physiol., 96, 588-596, 1991.

Fleitmann, D., Burns, S. J., Neff, U., Mudelsee, M., Mangini, A., and Matter, A.: Palaeoclimatic interpretation of highresolution oxygen isotope profiles derived from annually laminated speleothems from Southern Oman, Quaternary Sci. Rev., 23, 935-945, 2004.

Gerten, D., Schaphoff, S., Haberlandt, U., Lucht, W., and Sitch, S.: Terrestrial vegetation and water balance - hydrological evaluation of a dynamic global vegetation model, J. Hydrol., 286, 249270, 2004.

Gessler, A., Keitel, C., Kodama, N., Weston, C., Winters, A. J., Keith, H., Grice, K., Leuning, R., and Farquhar, G. D.: $\delta^{13} \mathrm{C}$ of organic matter transported from the leaves to the roots in Euca- 
lyptus delegatensis: short-term variations and relation to respired $\mathrm{CO}_{2}$, Funct. Plant Biol., 34, 692-706, 2007.

Gessler, A., Brandes, E., Buchmann, N., Helle, G., Rennenberg, H., and Barnard, R. L.: Tracing carbon and oxygen isotope signals from newly assimilated sugars in the leaves to the tree-ring archive, Plant Cell Environ., 32, 780-795, 2009.

Gessler, A., Brandes, E., Keitel, C., Boda, S., Kayler, Z. E., Granier, A., Barbour, M., Farquhar, G. D., and Treydte, K.: The oxygen isotope enrichment of leaf-exported assimilates - does it always reflect lamina leaf water enrichment?, New Phytol., 200, 144157, 2013.

Gessler, A., Pedro Ferrio, J., Hommel, R., Treydte, K., Werner, R. A., and Monson, R. K.: Stable isotopes in tree rings: towards a mechanistic understanding of isotope fractionation and mixing processes from the leaves to the wood, Tree Physiol., 34, 796818, 2014.

Haese, B., Werner, M., and Lohmann, G.: Stable water isotopes in the coupled atmosphere-land surface model ECHAM5JSBACH, Geosci. Model Dev., 6, 1463-1480, doi:10.5194/gmd6-1463-2013, 2013.

Harris, I., Jones, P. D., Osborn, T. J., and Lister, D. H.: Updated high-resolution grids of monthly climatic observations - the CRU TS3.10 Dataset, Int. J. Climatol., 34, 623-642, 2014.

Hartl-Meier, C., Zang, C., Buentgen, U., Esper, J., Rothe, A., Goettlein, A., Dirnboeck, T., and Treydte, K.: Uniform climate sensitivity in tree-ring stable isotopes across species and sites in a mid-latitude temperate forest, Tree Physiol., 35, 4-15, 2015.

Haxeltine, A. and Prentice, I. C.: A general model for the lightuse efficiency of primary production, Funct. Ecol., 10, 551-561, 1996a.

Haxeltine, A. and Prentice, I. C.: BIOME3: An equilibrium terrestrial biosphere model based on ecophysiological constraints, resource availability, and competition among plant functional types, Global Biogeochem. Cy., 10, 693-709, 1996b.

Herweijer, C., Seager, R., Cook, E. R., and Emile-Geay, J.: North American droughts of the last millennium from a gridded network of tree-ring data, J. Clim., 20, 1353-1376, 2007.

Hoffmann, G., Werner, M., and Heimann, M.: Water isotope module of the ECHAM atmospheric general circulation model: A study on timescales from days to several years, J. Geophys. Res.Atmos., 103, 16871-16896, 1998.

Hoffmann, G., Ramirez, E., Taupin, J. D., Francou, B., Ribstein, P., Delmas, R., Durr, H., Gallaire, R., Simoes, J., Schotterer, U., Stievenard, M., and Werner, M.: Coherent isotope history of Andean ice cores over the last century, Geophys. Res. Lett., 30, 1179, doi:10.1029/2002GL014870, 2003.

Holzkämper, S., Kuhry, P., Kultti, S., Gunnarson, B., and Sonninen, E.: Stable isotopes in tree rings as proxies for winter precipitation changes in the Russian Arctic over the past 150 years, Geochronometria, 32, 37-46, 2008.

Johnsen, S. J., Dahl-Jensen, D., Gundestrup, N., Steffensen, J. P., Clausen, H. B., Miller, H., Masson-Delmotte, V., Sveinbjörnsdottir, A. E., and White, J.: Oxygen isotope and palaeotemperature records from six Greenland ice-core stations: Camp Century, Dye-3, GRIP, GISP2, Renland and NorthGRIP, J. Quaternary Sci., 16, 299-307, 2001.

Joussaume, S., Sadourny, R., and Jouzel, J.: A general circulation model of water isotope cycles in the atmosphere, Nature, 311, 24-29, 1984.
Jouzel, J., Russell, G. L., Suozzo, R. J., Koster, R. D., White, J. W. C., and Broecker, W. S.: Simulations of the HDO and $\mathrm{H}_{2} \mathrm{O}^{18}$ atmospheric cycles using the NASA GISS general-circulation model - The seasonal cycle for present-day conditions, J. Geophys. Res.-Atmos., 92, 14739-14760, 1987.

Jouzel, J., Vimeux, F., Caillon, N., Delaygue, G., Hoffmann, G., Masson-Delmotte, V., and Parrenin, F.: Magnitude of isotope/temperature scaling for interpretation of central Antarctic ice cores, J. Geophys. Res.-Atmos., 108, 4361, doi:10.1029/2002JD002677, 2003.

Kahmen, A., Simonin, K., Tu, K., Goldsmith, G. R., and Dawson, T. E.: The influence of species and growing conditions on the 18-O enrichment of leaf water and its impact on "effective path length", New Phytol., 184, 619-630, 2009.

Kahmen, A., Sachse, D., Arndt, S. K., Tu, K. P., Farrington, H., Vitousek, P. M., and Dawson, T. E.: Cellulose $\delta^{18} \mathrm{O}$ is an index of leaf-to-air vapor pressure difference (VPD) in tropical plants, P. Natl. Acad. Sci. USA, 108, 1981-1986, 2011.

Kearney, M. R., Isaac, A. P., and Porter, W. P.: microclim: Global estimates of hourly microclimate based on longterm monthly climate averages, Scientific Data, 1, 140006, doi:10.1038/sdata.2014.6, 2014.

Kern, Z., Kohán, B., and Leuenberger, M.: Precipitation isoscape of high reliefs: interpolation scheme designed and tested for monthly resolved precipitation oxygen isotope records of an Alpine domain, Atmos. Chem. Phys., 14, 1897-1907, doi:10.5194/acp-14-1897-2014, 2014.

Kress, A., Saurer, M., Siegwolf, R. T. W., Frank, D. C., Esper, J., and Bugmann, H.: A 350 year drought reconstruction from Alpine tree ring stable isotopes, Global Biogeochem. Cy., 24, GB2011, doi:10.1029/2009GB003613, 2010.

Lamarque, J.-F., Kyle, G. P., Meinshausen, M., Riahi, K., Smith, S. J., van Vuuren, D. P., Conley, A. J., and Vitt, F.: Global and regional evolution of short-lived radiatively-active gases and aerosols in the Representative Concentration Pathways, Climatic Change, 109, 191-212, 2011.

Leuzinger, S. and Körner, C.: Tree species diversity affects canopy leaf temperatures in a mature temperate forest, Agr. Forest Meteorol., 146, 29-37, 2007.

Libby, L. M., Pandolfi, L. J., Payton, P. H., Marshall, J., Becker, B., and Giertz-Sienbenlist, V.: Isotopic tree thermometers, Nature, 261, 284-288, 1976.

MacFarling Meure, C., Etheridge, D., Trudinger, C., Steele, P., Langenfelds, R., van Ommen, T., Smith, A., and Elkins, J.: Law Dome $\mathrm{CO}_{2}, \mathrm{CH}_{4}$ and $\mathrm{N}_{2} \mathrm{O}$ ice core records extended to 2000 years BP, Geophys. Res. Lett., 33, L14810, doi:10.1029/2006GL026152, 2006.

Masson-Delmotte, V., Raffalli-Delerce, G., Danis, P. A., Yiou, P., Stievenard, M., Guibal, F., Mestre, O., Bernard, V., Goosse, H., Hoffmann, G., and Jouzel, J.: Changes in European precipitation seasonality and in drought frequencies revealed by a fourcentury-long tree-ring isotopic record from Brittany, western France, Clim. Dynam., 24, 57-69, 2005.

Masson-Delmotte, V., Steen-Larsen, H. C., Ortega, P., Swingedouw, D., Popp, T., Vinther, B. M., Oerter, H., Sveinbjornsdottir, A. E., Gudlaugsdottir, H., Box, J. E., Falourd, S., Fettweis, X., Gallée, H., Garnier, E., Gkinis, V., Jouzel, J., Landais, A., Minster, B., Paradis, N., Orsi, A., Risi, C., Werner, M., and White, J. W. C.: Recent changes in north-west Greenland climate documented by 
NEEM shallow ice core data and simulations, and implications for past-temperature reconstructions, The Cryosphere, 9, 14811504, doi:10.5194/tc-9-1481-2015, 2015.

McCarroll, D. and Loader, N. J.: Stable isotopes in tree rings, Quaternary Sci. Rev., 23, 771-801, 2004.

McDermott, F.: Palaeo-climate reconstruction from stable isotope variations in speleothems: a review, Quaternary Sci. Rev., 23, 901-918, 2004.

Miller, D. L., Mora, C. I., Grissino-Mayer, H. D., Mock, C. J., Uhle, M. E., and Sharp, Z.: Tree-ring isotope records of tropical cyclone activity, P. Natl. Acad. Sci., 103, 14294-14297, 2006.

Monteith, J. L.: A Reinterpretation of Stomatal Responses to Humidity, Plant Cell Environ., 18, 357-364, 1995.

Murray, S. J., Foster, P. N., and Prentice, I. C.: Evaluation of global continental hydrology as simulated by the Land-surface Processes and eXchanges Dynamic Global Vegetation Model, Hydrol. Earth Syst. Sci., 15, 91-105, doi:10.5194/hess-15-91-2011, 2011.

Noone, D. and Simmonds, I.: Associations between $\delta^{18} \mathrm{O}$ of water and climate parameters in a simulation of atmospheric circulation for 1979-95, J. Clim., 15, 3150-3169, 2002.

Offermann, C., Pedro Ferrio, J., Holst, J., Grote, R., Siegwolf, R., Kayler, Z., and Gessler, A.: The long way down-are carbon and oxygen isotope signals in the tree ring uncoupled from canopy physiological processes?, Tree Physiol., 31, 1088-1102, 2011.

Ogée, J., Barbour, M. M., Wingate, L., Bert, D., Bosc, A., Stievenard, M., Lambrot, C., Pierre, M., Bariac, T., Loustau, D., and Dewar, R. C.: A single-substrate model to interpret intra-annual stable isotope signals in tree-ring cellulose, Plant Cell Environ., 32, 1071-1090, 2009.

Prentice, I. C., Kelley, D. I., Foster, P. N., Friedlingstein, P., Harrison, S. P., and Bartlein, P. J.: Modeling fire and the terrestrial carbon balance, Global Biogeochem. Cy., 25, GB3005, doi:10.1029/2010GB003906, 2011.

Raddatz, T. J., Reick, C. H., Knorr, W., Kattge, J., Roeckner, E., Schnur, R., Schnitzler, K. G., Wetzel, P., and Jungclaus, J.: Will the tropical land biosphere dominate the climate-carbon cycle feedback during the twenty-first century?, Clim. Dynam., 29, 565-574, 2007.

Reynolds-Henne, C. E., Siegwolf, R. T. W., Treydte, K. S., Esper, J., Henne, S., and Saurer, M.: Temporal stability of climate-isotope relationships in tree rings of oak and pine (Ticino, Switzerland), Global Biogeochem. Cy., 21, 1-12, 2007.

Rinne, K. T., Loader, N. J., Switsur, V. R., and Waterhouse, J. S.: 400-year May-August precipitation reconstruction for Southern England using oxygen isotopes in tree rings, Quaternary Sci. Rev., 60, 13-25, 2013.

Ripullone, F., Matsuo, N., Stuart-Williams, H., Wong, S. C., Borghetti, M., Tani, M., and Farquhar, G.: Environmental Effects on Oxygen Isotope Enrichment of Leaf Water in Cotton Leaves, Plant Physiol., 146, 729-736, 2008.

Risi, C., Bony, S., Vimeux, F., and Jouzel, J.: Water-stable isotopes in the LMDZ4 general circulation model: Model evaluation for present-day and past climates and applications to climatic interpretations of tropical isotopic records, J. Geophys. Res.-Atmos., 115, D12118, doi:10.1029/2009JD013255, 2010.

Roden, J. S., Lin, G. G., and Ehleringer, J. R.: A mechanistic model for interpretation of hydrogen and oxygen isotope ratios in treering cellulose, Geochim. Cosmochim. Ac., 64, 21-35, 2000.
Roeckner, E., Bäuml, G., Bonaventura, L., Brokopf, R., Esch, M., Giorgetta, M., Hagemann, S., Kirchner, I., Kornblueh, L., Manzini, E., Rhodin, A., Schlese, U., Schulzweida, U., and Tompkins, A.: The atmospheric general circulation model ECHAM5 - Part 1, Max-Planck-Institut für Meteorologie, Report No. 349, 2003.

Rozanski, K., Araguasaraguas, L., and Gonfiantini, R.: Relation between long-term trends of ${ }^{18} \mathrm{O}$ isotope composition of precipitation and climate, Science, 258, 981-985, 1992.

Ruosch, M., Spahni, R., Joos, F., Henne, P. D., van der Knaap, P., and Tinner, W.: Past and future evolution of Abies alba forests in Europe - comparison of a dynamic vegetation model with palaeo data and observations, Glob. Change Biol., 22, 727-740, 2016.

Sarris, D., Siegwolf, R., and Körner, C.: Inter- and intra-annual stable carbon and oxygen isotope signals in response to drought in Mediterranean pines, Agr. Forest Meteorol., 168, 59-68, 2013.

Saurer, M., Schweingruber, F., Vaganov, E. A., Shiyatov, S. G., and Siegwolf, R.: Spatial and temporal oxygen isotope trends at the northern tree-line in Eurasia, Geophys. Res. Lett., 29, 1296, doi:10.1029/2001GL013739, 2002.

Saurer, M., Spahni, R., Frank, D. C., Joos, F., Leuenberger, M., Loader, N. J., McCarroll, D., Gagen, M., Poulter, B., Siegwolf, R. T. W., Andreu-Hayles, L., Boettger, T., Dorado Linan, I., Fairchild, I. J., Friedrich, M., Gutierrez, E., Haupt, M., Hilasvuori, E., Heinrich, I., Helle, G., Grudd, H., Jalkanen, R., Levanic, T., Linderholm, H. W., Robertson, I., Sonninen, E., Treydte, K., Waterhouse, J. S., Woodley, E. J., Wynn, P. M., and Young, G. H. F.: Spatial variability and temporal trends in water-use efficiency of European forests, Glob. Change Biol., 20, 3700-3712, 2014.

Schär, C., Vidale, P. L., Lüthi, D., Frei, C., Häberli, C., Liniger, M. A., and Appenzeller, C.: The role of increasing temperature variability in European summer heatwaves, Nature, 427, 332336, 2004.

Severinghaus, J. P., Beaudette, R., Headly, M. A., Taylor, K., and Brook, E. J.: Oxygen- 18 of $\mathrm{O}_{2}$ Records the Impact of Abrupt Climate Change on the Terrestrial Biosphere, Science, 324, 14311434, 2009.

Shackleton, N. J. and Obdyke, N. D.: Oxygen-isotope and paleomagnetic stratigraphy of equatorial Pacific core V28-238: oxygen-isotope temperatures and ice volumes on an $10^{5}$ year to $10^{6}$ year scale, Quaternary Res., 3, 39-55, 1973.

Sidorova, O. V., Siegwolf, R. T. W., Saurer, M., Naurzbaev, M. M., and Vaganov, E. A.: Isotopic composition $\left(\delta^{13} \mathrm{C}, \delta^{18} \mathrm{O}\right)$ in wood and cellulose of Siberian larch trees for early Medieval and recent periods, J. Geophys. Res.-Biogeo., 113, G02019, doi:10.1029/2007JG000473, 2008.

Sitch, S., Smith, B., Prentice, I. C., Arneth, A., Bondeau, A., Cramer, W., Kaplan, J. O., Levis, S., Lucht, W., Sykes, M. T., Thonicke, K., and Venevsky, S.: Evaluation of ecosystem dynamics, plant geography and terrestrial carbon cycling in the LPJ dynamic global vegetation model, Glob. Change Biol., 9, 161-185, 2003.

Sjolte, J., Hoffmann, G., Johnsen, S. J., Vinther, B. M., MassonDelmotte, V., and Sturm, C.: Modeling the water isotopes in Greenland precipitation 1959-2001 with the meso-scale model REMO-iso, J. Geophys. Res.-Atmos., 116, 1-22, 2011. 
Song, X., Clark, K. S., and Helliker, B. R.: Interpreting speciesspecific variation in tree-ring oxygen isotope ratios among three temperate forest trees, Plant Cell Environ., 37, 2169-2182, 2014.

Spahni, R., Joos, F., Stocker, B. D., Steinacher, M., and Yu, Z. C.: Transient simulations of the carbon and nitrogen dynamics in northern peatlands: from the Last Glacial Maximum to the 21st century, Clim. Past, 9, 1287-1308, doi:10.5194/cp-9-1287-2013, 2013.

Sternberg, L. and Ellsworth, P. F. V.: Divergent Biochemical Fractionation, Not Convergent Temperature, Explains Cellulose Oxygen Isotope Enrichment across Latitudes, PLoS ONE, 6, e28040, doi:10.1371/journal.pone.0028040, 2011.

Sternberg, L. d. S. L.: Comment on "Oxygen isotope ratios $\left({ }^{18} \mathrm{O} /{ }^{16} \mathrm{O}\right)$ of hemicellulose-derived sugar biomarkers in plants, soils and sediments as paleoclimate proxy I: Insight from a climate chamber experiment" by Zech et al. (2014), Geochim. Cosmochim. Ac., 141, 677-679, 2014.

Sternberg, L. d. S. L., DeNiro, M. J., and Savidge, R. A.: Oxygen Isotope Exchange between Metabolites and Water during Biochemical Reactions Leading to Cellulose Synthesis, Plant Physiol., 82, 423-427, 1986.

Sternberg, L. d. S. L. O. R.: Oxygen stable isotope ratios of tree-ring cellulose: the next phase of understanding, New Phytol., 181, 553-562, 2009.

Stocker, B. D., Roth, R., Joos, F., Spahni, R., Steinacher, M., Zaehle, S., Bouwman, L., Xu, R., and Prentice, I. C.: Multiple greenhouse-gas feedbacks from the land biosphere under future climate change scenarios, Nature Climate Change, 3, 666-672, 2013.

Sturm, K., Hoffmann, G., Langmann, B., and Stichler, W.: Simulation of $\delta^{18} \mathrm{O}$ in precipitation by the regional circulation model REMO $_{\text {iso }}$, Hydrol. Proc., 19, 3425-3444, 2005.

Treydte, K., Frank, D., Esper, J., Andreu, L., Bednarz, Z., Berninger, F., Boettger, T., D’Alessandro, C. M., Etien, N., Filot, M., Grabner, M., Guillemin, M. T., Gutierrez, E., Haupt, M., Helle, G., Hilasvuori, E., Jungner, H., Kalela-Brundin, M., Krapiec, M., Leuenberger, M., Loader, N. J., Masson-Delmotte, V., Pazdur, A., Pawelczyk, S., Pierre, M., Planells, O., Pukiene, R., Reynolds-Henne, C. E., Rinne, K. T., Saracino, A., Saurer, M., Sonninen, E., Stievenard, M., Switsur, V. R., Szczepanek, M., Szychowska-Krapiec, E., Todaro, L., Waterhouse, J. S., Weigl, M., and Schleser, G. H.: Signal strength and climate calibration of a European tree-ring isotope network, Geophys. Res. Lett., 34, 1-6, 2007.

Treydte, K., Boda, S., Pannatier, E. G., Fonti, P., Frank, D., Ullrich, B., Saurer, M., Siegwolf, R., Battipaglia, G., Werner, W., and Gessler, A.: Seasonal transfer of oxygen isotopes from precipitation and soil to the tree ring: source water versus needle water enrichment, New Phytol., 202, 772-783, 2014.
Treydte, K. S., Schleser, G. H., Helle, G., Frank, D. C., Winiger, M., Haug, G. H., and Esper, J.: The twentieth century was the wettest period in northern Pakistan over the past millennium, Nature, 440, 1179-1182, 2006.

Wang, X. F., Yakir, D., and Avishai, M.: Non-climatic variations in the oxygen isotopic compositions of plants, Glob. Change Biol., 4, 835-849, 1998.

Wania, R., Ross, I., and Prentice, I. C.: Integrating peatlands and permafrost into a dynamic global vegetation model: 2. Evaluation and sensitivity of vegetation and carbon cycle processes, Global Biogeochem. Cy., 23, GB3015, doi:10.1029/2008GB003413, 2009.

Waterhouse, J. S., Switsur, V. R., Barker, A. C., Carter, A. H. C., and Robertson, I.: Oxygen and hydrogen isotope ratios in tree rings: how well do models predict observed values?, Earth Planet. Sc. Lett., 201, 421-430, 2002.

Weigt, R. B., Bräunlich, S., Zimmermann, L., Saurer, M., Grams, T. E. E., Dietrich, H.-P., Siegwolf, R. T. W., and Nikolova, P. S.: Comparison of $\delta^{18} \mathrm{O}$ and $\delta^{13} \mathrm{C}$ values between tree-ring whole wood and cellulose in five species growing under two different site conditions, Rapid Commun. Mass Sp., 29, 2233-2244, 2015.

Werner, M., Langebroek, P. M., Carlsen, T., Herold, M., and Lohmann, G.: Stable water isotopes in the ECHAM5 general circulation model: Toward high-resolution isotope modeling on a global scale, J. Geophys. Res.-Atmos., 116, D15109, doi:10.1029/2011JD015681, 2011.

Wershaw, R. L., Friedman, I., Heller, S. J., and Frank, P. A.: Hydrogen isotope fractionation of water passing through trees, in: Advances in organic geochemistry, edited by: Hobson, G. D., Pergamon Press, Oxford, 55-67, 1966.

West, J. B., Sobek, A., and Ehleringer, J. R.: A Simplified GIS Approach to Modeling Global Leaf Water Isoscapes, PLoS ONE, 3, e2447, doi:10.1371/ journal.pone.0002447, 2008.

Xu, G., Liu, X., Qin, D., Chen, T., Wang, W., Wu, G., Sun, W., An, W., and Zeng, X.: Relative humidity reconstruction for northwestern China's Altay Mountains using tree-ring $\delta^{18} \mathrm{O}$, Chinese Sci. Bull., 59, 190-200, 2014.

Zech, M., Mayr, C., Tuthorn, M., Leiber-Sauheitl, K., and Glaser, B.: Reply to the comment of Sternberg on "Zech et al. (2014) Oxygen isotope ratios $\left({ }^{18} \mathrm{O} /{ }^{16} \mathrm{O}\right)$ of hemicellulose-derived sugar biomarkers in plants, soils and sediments as paleoclimate proxy I: Insight from a climate chamber experiment, GCA 126, 614-623”, Geochim. Cosmochim. Ac., 141, 680-682, 2014. 